University of New Hampshire

University of New Hampshire Scholars' Repository

\title{
High Frequency Concurrent Measurements in Watershed and Impaired Estuary Reveal Coupled DOC and Decoupled Nitrate Dynamics
}

\author{
Gopal K. Mulukutla \\ University of New Hampshire, Durham, gopal.mulukutla@unh.edu \\ Wilfred Wollheim \\ University of New Hampshire, Durham \\ Joseph Salisbury

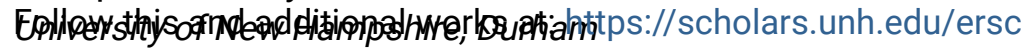 \\ kichartaf the Bigeygechemistry Commons, Hydrology Commons, and the Water Resource Management \\ Apassaehasetts Department of Environmental Protection

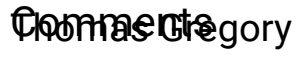



Citation for the final published version:

Mulukutla, G.K. Wollheim.W.M, Saljsbury, J.E. et al. High-Frequency Concurrent Measurements in Watershed and See next'pagè for additional'authors

Impaired Estuary Reveal Coupled DOC and Decoupled Nitrate Dynamics. Estuaries and Coasts (2021). https://doi.org/

$10.1007 / \mathrm{s} 12237-021-00965-8$

\section{Recommended Citation}

Mulukutla, Gopal K.; Wollheim, Wilfred; Salisbury, Joseph; Carey, Richard O.; Gregory, Thomas; and McDowell, William H., "High Frequency Concurrent Measurements in Watershed and Impaired Estuary Reveal Coupled DOC and Decoupled Nitrate Dynamics" (2021). Earth Systems Research Center. 216. https://scholars.unh.edu/ersc/216

This Article is brought to you for free and open access by the Institute for the Study of Earth, Oceans, and Space (EOS) at University of New Hampshire Scholars' Repository. It has been accepted for inclusion in Earth Systems Research Center by an authorized administrator of University of New Hampshire Scholars' Repository. For more information, please contact Scholarly.Communication@unh.edu. 
Authors

Gopal K. Mulukutla, Wilfred Wollheim, Joseph Salisbury, Richard O. Carey, Thomas Gregory, and William H. McDowell

This article is available at University of New Hampshire Scholars' Repository: https://scholars.unh.edu/ersc/216 
1 High Frequency Concurrent Measurements in Watershed and

Dynamics.

4

\section{Gopal K. Mulukutla ${ }^{1}$, Wilfred M. Wollheim ${ }^{1,2}$, Joseph E. Salisbury ${ }^{3}$,} Richard O. Carey ${ }^{4}$, Thomas K. Gregory ${ }^{3}$ and William H. McDowell ${ }^{2}$

\author{
${ }^{1}$ Earth Systems Research Center, University of New Hampshire, Durham, New \\ Hampshire, USA. \\ 2Department of Natural Resources and the Environment, University of New Hampshire, \\ Durham, New Hampshire, USA \\ ${ }^{3}$ Ocean Processes Analysis Laboratory, University of New Hampshire, Durham, New \\ Hampshire, USA \\ ${ }^{4}$ Massachusetts Department of Environmental Protection, Worcester, Massachusetts, USA
}

Key Points:

- Simultaneous water quality measurements in watershed and N-impaired estuary show strong watershed control for estuarine DOC but complex coupling for nitrate.

- DOC exhibited near-conservative behavior in the estuary.

- For nitrate, watershed spatial distribution of sources and interaction with estuarine internal process to produce complex response.

Corresponding author: Gopal Mulukutla (gopal.mulukutla@unh.edu) 


\section{Abstract}

38 Rapid changes in land use, pollution inputs, and climate are altering the quantity, timing and

39 form of materials delivered from watersheds to estuaries. To better characterize these alterations

40 simultaneous measurements of biogeochemical conditions in watersheds and estuaries over a

41 range of times scales are needed. We examined the strength of watershed-estuarine

42 biogeochemical coupling using data of in situ measurements of nitrate, terrestrial dissolved organic

43 carbon (DOC) and chloride collected over a seven-month period in a nitrogen impaired estuary in

44 the northeastern US. The watershed was observed exerting strong control over concentrations of

45 terrestrially derived DOC in the estuary, attributable to relative homogeneity of watershed sources

46 derived from forested land use combined with relatively conservative behavior in estuarine waters.

47 Estuarine nitrate patterns were more complex, suggesting the influence of heterogeneous

48 watershed distribution of non-point and point sources and high reactivity of nitrate in the estuary.

49 Understanding estuarine biogeochemical patterns will be advanced through greater use of

50 simultaneous sub-hourly measurements of inflows, salinity and water quality estuaries and their

51 upstream watersheds.

52 


\section{$53 \quad$ 1.0 Introduction}

54 Estuaries are strongly influenced by inputs of freshwater, nutrients, and carbon from coastal

55 watersheds. The degree of influence is determined by several factors that can vary over space and

56 time, including magnitude and frequency of storms, estuarine residence time relative to watershed

57 area, the degree of anthropogenic activity, and consequent changes in land use composition (Arndt

58 et al., 2007; Pinckney et al., 2001; Salisbury et al., 2008; Swaney et al., 2008). Eutrophication of

59 estuarine waters due to $\mathrm{N}$ enrichment is increasing, causing many problems such as loss of

60 biodiversity, increased algal blooms, anoxic water, acceleration of species invasions, and shifts in

61 dominant biogeochemical pathways (Barbier et al., 2011; McClelland \& Valiela, 1998; Smyth et al.,

62 2013; Wetz \& Yoskowitz, 2013). Watershed inputs of DOC to coastal areas are also occurring,

63 potentially impacting light regimes and foodwebs (Balch et al., 2016). As a result, the ability of

64 estuaries to provide important ecosystem services is continuing to decline (Deegan et al., 2012;

65 Grabowski \& Peterson, 2007).

Human activities alter the amount and timing of nutrient and organic matter inputs delivered to

67 estuaries (Bowen \& Valiela, 2008). Both watershed drivers and estuarine responses are further

68 influenced by factors such as climate change and associated changes in temperature, sea levels,

69 wind patterns, and the hydrologic cycle(Bricker et al., 2008; Salisbury et al., 2009; Statham, 2012).

70 Increases in anthropogenic $\mathrm{N}$ and changes to organic matter fluxes are occurring in the watershed

71 due to expanding agriculture, urbanization, and associated land use change. Although much

72 anthropogenic $\mathrm{N}$ is retained in watersheds (Boyer et al., 2002) increased loading leads to increased

73 export through rivers and streams (Seitzinger \& Kroeze, 1998). Estuaries modulate exports of DOC

74 (and other forms of carbon) with high in situ production rates, and spatial and temporal

75 heterogeneity(Bauer et al., 2013). This has resulted in studies that report near-conservative

76 behavior of DOC in some estuaries(Mantoura \& Woodward, 1983; Vallino et al., 2005), non-

77 conservative behavior in some (McKenna, 2004), while laboratory studies show terrestrial DOC to 
78 be highly reactive due to "salting out" or microbial degradation(Battin et al., 2009; Moran et al.,

79 1999; Schlesinger \& Bernhardt, 2013). Furthermore, hydrologic conditions can strongly influence

80 the mobilization, transport, and retention of nutrients and carbon within watersheds (Kaushal et

81 al., 2014; Morse \& Wollheim, 2014). Thus, with climate change, the controlling mechanisms of

82 estuarine conditions will also likely change.

83 Watershed-estuary coupling can occur continuously during periods of baseflow or

84 episodically during stormflow. An estuary responds to watershed and environmental drivers over

85 multiple temporal scales (Cloern \& Nichols, 1985) (a) short duration driven by daylight or tides, (b)

86 storm event scale, driven by freshwater inflows lasting hours to weeks, (c) seasonal, due to changes

87 in precipitation, temperature, and watershed function, and (d) annual, due to longer term climate

88 oscillations and trends. Previous estuarine studies focused on seasonal or annual time scales that

89 combined infrequent observations of biogeochemical characteristics (e.g., weekly or monthly) with

90 finer temporal scale observations of inflows (Clair et al., 2013; Valiela \& Bowen, 2002). However, a

91 focus on broader time scales limits understanding of estuarine responses at finer time scales

92 (Bergamaschi, Fleck, et al., 2012; Bergamaschi, Krabbenhoft, et al., 2012; Robins et al., 2018). For

93 example, during storms, patterns in $\mathrm{N}$ concentration exported from watersheds may exhibit

94 increase, decrease or remain chemostatic with flow depending watershed or time period(Godsey et

95 al., 2009). Estuarine storm response may or may not reflect watershed patterns due to complicated

96 circulation, stratification, or strong biological activity. Knowledge of these patterns often requires

97 simultaneous sub-daily measurements in both watershed and estuary.

98 The emergence of in situ sensor technologies capable of continuous biogeochemical

99 measurements provide opportunities to improve the understanding of watershed-estuary linkages

100 (Bergamaschi, Krabbenhoft, et al., 2012). Sensors can perform autonomous high temporal

101 frequency (sub-hourly) and long term (>3 months) measurements of key biogeochemical variables 
102 including nitrate, phosphate, and dissolved organic carbon (DOC) via an optical proxy (fluorescent

103 dissolved organic matter, fDOM)(Downing et al., 2012), as well as classic water quality parameters

104 in watersheds (Carey et al., 2014; Saraceno et al., 2009) and marine waters (O’Boyle et al., 2014).

105 However, only a few studies have implemented concurrent watershed-estuary systems to study

106 biogeochemical coupling and its implications for estuarine conditions (Gilbert et al., 2013).

107 The objective of this study was to examine seasonal and storm event dynamics of estuarine

108 nitrate and DOC using simultaneous measurements of river and estuarine chemistry. We

109 conducted this study in Great Bay, New Hampshire, USA, and in the watershed of its largest

110 tributary, Lamprey River. This estuary system faces long-term land-use change and increasing

111 climate variability. We hypothesized that: a) storm-event watershed nitrate and DOC fluxes will

112 provide greater control on corresponding estuarine concentrations and that the estuary will show

113 minimal coupling during baseflow, b) due to the spatial homogeneity of watershed sources,

114 estuarine DOC will respond more to storm-event watershed DOC fluxes than estuarine nitrate to

115 nitrate fluxes, and c) for both nitrate and DOC, monitoring in one sub-watershed will not be fully

116 representative of variability observed in estuarine conditions.

\section{$117 \quad 2.0$ Study Site and Methods}

118 The Great Bay estuary is located in Northeastern USA (Figure 1). The estuary system consists of

119 nine major sub-watersheds formed by seven major tributaries (Table 1). The watershed (2651

$120 \mathrm{~km}^{2}$ ) has a population of 400,000 people living in 55 urbanizing municipalities (Mills, 2009; P

121 Trowbridge et al., 2014; Phil Trowbridge, 2007). The estuarine system is strongly tidal with

122 relatively shallow morphology marked by limited vertical stratification (Short, 1992), a large

123 volume relative to inputs, and long baseflow residence time (13-20 days, Text S1, supporting

124 information). Great Bay is showing signs of eutrophication attributed mainly to nitrogen over-

125 enrichment from both point (32\%) and non-point sources (68\%) (PREP, 2013). Increased N loads

126 (42\%) in recent years (Bresler, 2012; P. Trowbridge, 2010) have contributed to greater prevalence 
127 of phytoplankton and nuisance macroalgae, and leading the US-EPA to list it as N-impaired with

128 regulations proposed such as expensive upgrades to waste water treatment plants (WWTP).

129 Increased storm activity in the region (Douglas et al., 2011) has also increased inputs of terrestrial

130 DOC and turbidity to coastal waters (Balch et al., 2016). Together, these changes have led to

131 reduced water clarity and light penetration, possibly contributing to an observed drastic reduction

132 in the spread of eelgrass, the estuary's cornerstone vegetation (Beem \& Short, 2009). Focus of this

133 study is Great Bay proper, the largest sub-estuary in the estuarine system, and the Lamprey River

134 sub-watershed (Figure 1).

\section{$135 \quad 2.1$ Measurements}

136 Continuous, high frequency (every 30 minutes) measurements of nitrate, fDOM and

137 conductance/salinity were made using in situ sensors deployed simultaneously in the estuary and

138 its tributary, the Lamprey River (Figure 2). Sensors were deployed for one growing season (May -

139 November 2011). River flow data were obtained from a co-located discharge gage operated by the

140 US Geological Survey (\#01073500 Lamprey River near Newmarket, NH). A linear regression

141 between weekly grab measurements ( $\mathrm{DOC}, \mathrm{NO}_{3}$, and, $\mathrm{Cl}$ ) and corresponding sensor variable (fDOM,

$142 \mathrm{NO}_{3}$, specific conductance) was used to correct sensor measurements. Instantaneous watershed

143 fluxes were estimated at a given instant of time, $f(t)$ as:

$144 \quad f(t)=C(t) * Q(t)$

145 Where $C(t)$ is the measured concentration of the constituent, and $Q(t)$ is the flow across the

146 river at time instant $t$.

\section{$147 \quad$ 2.3 Data Analysis Methods}

\section{Data pre-processing}

149 Individual time series variables were first quality controlled by removing outliers and

150 replacing them initially with an "NaN" ( not a number). Missing data points were also identified 
151 using an "NaN". Segments of data with "NaNs" were then linearly interpolated to remove any

152 missing data and make the time series temporally continuous allowing the application of time

153 series techniques described below. Tidal influences on the time series of estuarine variables were

154 removed using a low-pass filter (Johnson et al., 2006). According to this procedure, the Fourier

155 transform of the signal was first computed. The amplitude of spectral frequencies higher than

1561.375 cycles per day were zeroed to remove the dominant semi-diurnal component. The signal was

157 then reconstructed through an inverse Fourier transform. The reconstructed signal developed by

158 applying this technique contains only the weaker tidal frequencies along with any variability caused

159 by diel biological processing.

\section{Time series methods}

161 We applied frequency dependent coherence, $(\mathrm{C} ; 0<\mathrm{C}<1)$ a time series analysis technique, to

162 evaluate how estuarine concentrations $\left(\mathrm{NO}_{3}, \mathrm{fDOM}\right.$ and $\left.\mathrm{Cl}\right)$ vary over time in conjunction with a

163 related watershed variable (freshwater inflows; $\mathrm{NO}_{3}, \mathrm{DOC}$ and $\mathrm{Cl}$ concentration and fluxes). Given

164 two time series $\mathrm{u}(\mathrm{t})$ and $\mathrm{v}(\mathrm{t})$ frequency dependent coherence within a narrow band of frequency

$165(\Delta \omega)$ with center at $\omega_{0}$ is given as (Menke \& Menke, 2012)

166

$$
C_{u v}^{2}\left(\omega_{0}, \Delta \omega\right)=\frac{\left|\widetilde{u}^{*}\left(\omega_{0}\right) \tilde{v}\left(\omega_{0}\right)\right|^{2}}{\left|\widetilde{u}\left(\omega_{0}\right)\right|^{2}\left|\tilde{v}\left(\omega_{0}\right)\right|^{2}}
$$

167 Where $\tilde{u}\left(\omega_{0}\right)$ and $\tilde{v}\left(\omega_{0}\right)$ are the Fourier transforms of $\mathrm{u}(\mathrm{t})$ and $\mathrm{v}(\mathrm{t})$, at frequency $\omega_{0}$, respectively, 168 and $\tilde{u}^{*}\left(\omega_{0}\right)$ is the Fourier transform of time reversed $u(t)$, at frequency $\omega_{0}$. The coherence profile is

169 constructed by applying Eq. (2) over the entire frequency range of a signal. Coherence values

170 reported here are denoted by subscripted variable $\bar{C}_{E-R}$, where overbar represents an average

171 coherence over a given time period, and $E$ and $R$ represent (filtered) estuarine constituent

172 concentration and watershed variable respectively.

\section{Storm Event Delineation}

174 We examined individual storm event patterns between estuarine concentrations and

175 watershed nutrient fluxes (hysteresis) to determine intra-storm watershed-estuary coupling. 
176 These patterns are analogous to the concentration-discharge relationships observed in watersheds

177 (Carey et al., 2014; Evans \& Davies, 1998). We analyzed 13 freshwater storm events for the

178 influence of freshwater discharge, $\mathrm{DOC}$, and $\mathrm{NO}_{3}$ fluxes on estuarine concentration patterns. River

179 flow data was obtained from a discharge gage operated by the US Geological Survey (USGS

18001073500 Lamprey River near Newmarket, NH).

181 Each storm was partitioned by 3 points: the start of the storm (beginning of rising limb),

182 peak flow (beginning of falling limb), and end of the storm (termination of falling limb). The

183 beginning of a storm event was identified based on a minimum flow increase of $1.5 \mathrm{~m}^{3} / \mathrm{s}$ (see

184 Figure 3). The end of storm was determined by identifying the earliest point since the beginning of

185 a storm that was within $0.5 \mathrm{~m}^{3} / \mathrm{s}$ of observed baseflow. Some storm events constituted two or

186 more high flow points; a consequence of a lull followed by more precipitation. For this study such

187 events were identified as a single storm event with highest among the multiple high flows identified

188 as peak storm flow. Also, the beginning of the increase in flow identified for the earliest peak and

189 the end of the flow identified for the latest peak were selected as the beginning and end of the

190 storm event respectively (Figure 3).

191 Storm characteristics examined include: overall estuarine concentration response

192 (increase/decrease), rotational pattern (clockwise/anti-clockwise/multi-loop), and degree of

193 coupling between watershed and estuary where degree of storm event-scale coupling is defined

194 using a power-law function, $\mathrm{P}=\mathrm{b} \mathrm{F}^{\alpha}$, where $\mathrm{P}$ is estuarine constituent concentration, $\mathrm{F}$ is watershed

195 flux of a given constituent, $b$ and $\alpha$ are fitted parameters(Basu et al., 2010; Godsey et al., 2009). We

196 applied this to individual rising and falling limbs of storm-event watershed inputs. An $\alpha$ (estuarine

197 responsiveness) that is positive indicates increased estuarine concentrations resulting from storm

198 inputs. A zero or non-significant exponent indicates no coupling, while a negative exponent

199 indicates declining concentrations resulting from storm inputs. 


\section{$201 \quad 3.1$ Watershed and Estuarine Biogeochemical Patterns}

202 Estuarine fDOM tracks well with watershed DOC fluxes (Figure 2a), with a pattern of high

203 concentrations observed during high runoff in spring and autumn ( $\sim 60$ quinine sulfate equivalent

204 parts per billion (QSE-ppb)) and lower concentrations during summer low flows ( $\sim 30$ QSE-ppb).

205 Terrestrial DOC is the major portion of observed fDOM response (4.04 QSE-ppb recorded at salinity 206 of $32 \mathrm{psu}$ ). Through the rest of this discussion fDOM will be used interchangeably with "terrestrial

207 DOC". Each storm event peak in DOC flux is followed closely by a peak in fDOM. Watershed $\mathrm{NO}_{3}$

208 fluxes and estuarine $\mathrm{NO}_{3}$ concentrations (Figure $2 \mathrm{~b}$ ) also show high levels in late spring and fall

209 (0.1-0.2 mg NL-1), and lows in the summer $\left(<0.05 \mathrm{mg} \mathrm{NL}^{-1}\right)$. But in contrast to fDOM, estuarine $\mathrm{NO}_{3}$

210 concentrations show less pronounced response to storm-event flows (Figure 2b).

211 Partitioning response time scales provided by coherence analysis allows insights into

212 watershed-estuary coupling. Frequency dependent coherence response of each estuarine

213 constituent ( $\mathrm{Cl}$, $\mathrm{fDOM}, \mathrm{NO}_{3}$ concentrations) was examined by pairing initially with watershed

214 discharge (Figure 4a) and then with respective watershed concentrations (Figure 4b) and flux

215 (Figure 4c). Given that river discharge varies over several orders of magnitude while

216 concentrations of most constituents are less variable (Godsey et al., 2009; Kirchner \& Neal, 2013),

217 we would expect that coherence between estuarine concentrations and watershed fluxes would be

218 stronger than coherence between estuary and watershed concentrations

Over the study period using time scales greater than one day the average coherence of

220 estuarine constituent concentrations was highest when related to watershed discharge (Table 3)

221 with all three constituents exhibiting similar levels of coherence $\left(\bar{C}_{N O 3-Q}=0.21, \bar{C}_{f D O M-Q}=0.22\right.$,

$\left.222 \bar{C}_{C l-Q}=0.17\right)$. Coherence was much lower when relating estuarine concentrations with watershed

223 concentrations $\left(\bar{C}_{\mathrm{NO}-\mathrm{NO}}=0.05, \bar{C}_{f D O M-D O C}=0.09, \bar{C}_{C l-C l}=0.11\right)$ (Figure $\left.4 \mathrm{~b}\right)$. Coherence 
224 between estuarine DOC and $\mathrm{Cl}$ and corresponding watershed DOC and Cl fluxes were similar to

225 those when using discharge, while coherence between estuarine $\mathrm{NO}_{3}$ and watershed $\mathrm{NO}_{3}$ fluxes was

226 lower than when using discharge $\left(\bar{C}_{\text {NO3-NO3flux }}=0.13, \bar{C}_{f D O M-D O C f l u x}=0.21, \bar{C}_{C l-C l f l u x}=0.16\right)$.

227 Over long time scales ( $>100$ days) coherences were high between estuarine fDOM, $\mathrm{NO}_{3}$, and

$228 \mathrm{Cl}$ and corresponding watershed constituent fluxes (Figure $4 \mathrm{c}, \bar{C}_{\mathrm{NO} 3-\mathrm{NO} \text { flux }}=0.99$,

$229 \bar{C}_{f D O M-D O C f l u x}=0.95, \bar{C}_{C l-C l f l u x}=0.73$ ) indicating the predominant role of freshwater inputs over

230 seasonal time scales . Likewise, coherences between concentrations and fluxes over short time

231 scales (<6 days) are very low $\left(\bar{C}_{N O 3-N O 3 f l u x}=0.07, \bar{C}_{f D O M-D O C f l u x}=0.11, \bar{C}_{C l-C l f l u x}=0.07\right)$

232 suggesting the watershed has minimal influence over estuarine variability over these time scales.

233 At intermediate time scales (6 - 30 days), a time span that encompasses storm flows (Table

234 1), the response of estuarine concentrations to watershed fluxes for all three constituents was

235 observed to be intermediate in magnitude. Coherence between estuarine concentrations and

236 watershed flux was much greater than when using watershed concentration across all time scales

237 (Figure 4b) and were similar or lower than when using discharge (Figure 4a).

238 When using watershed fluxes, $\mathrm{NO}_{3}$ coherence was lower than DOC or $\mathrm{Cl}$ across all time

239 scales, and especially during intermediate scales (Figure 4c). For both $\mathrm{Cl}$ and DOC, there is a broad

240 peak approached by around 7 days (Figure 4c) with declines occurring around 20 days. In contrast,

$241 \mathrm{NO}_{3}$ coherence also peaks around 7-9 days but the decline occurs much earlier and rapidly at

242 around 15 days. Average coherence during this period is higher for DOC than for $\mathrm{NO}_{3}$

$243\left(\bar{C}_{f D O M-D O C f l u x}=0.67, \bar{C}_{\text {NO3-NO3flux }}=0.38\right)$. The observed response at intermediate time scale is

244 a collective indication of watershed inputs from all storm events.

245 These results suggest that over the course of the year flows drive variability in estuarine 246 concentrations, while changes in watershed concentrations are secondary. Although coherence 
247 with discharge was similar or better when using watershed fluxes, we chose constituent fluxes as

248 the basis for further study because in principle they should provide better coherence and because

249 time scales where this is not true may be informative.

\section{$250 \quad 3.2$ Storm Event Patterns}

In our examination of storm-event patterns in estuarine concentration Vs. watershed fluxes,

252 some hysteresis naturally occurs due to the spatial separation between watershed and estuarine

253 monitoring locations. Consequently, the peak/minimum in the estuarine variable occurs after the

254 peak/minimum in the watershed variable. We did not correct the data for such lags. However,

255 where it could be characterized lags were found to not affect our results (section S2, supporting

256 information).

The hysteresis response observed over the whole period of deployment (Figure 5) the

258 estuarine response is a superposition of loops organized by season and estuary responding

259 positively to increased watershed fluxes. In contrast, individual storm response is complex as

260 shown in hysteresis plots in the supporting information(Figures S1-S13). Storms generally modify

261 estuarine conditions from the pre-storm state for each constituent (Figure 2), but the strength of

262 response varies with constituent, storm size and time of year. Initial conditions, just prior to a

263 storm-event, for nitrate and DOC show a strong positive correlation with watershed fluxes, while $\mathrm{Cl}$

264 shows a strong negative correlation (Figure 6 )(DOC: $\mathrm{R}^{2}=0.72 ; \mathrm{NO}_{3}: \mathrm{R}^{2}=0.87 ; \mathrm{Cl}^{2} \mathrm{R}^{2}=0.79$, all

$265 \mathrm{p}<0.05)$.

Storms generally tend to increase $\mathrm{fDOM}$ and $\mathrm{NO}_{3}$ and reduce $\mathrm{Cl}$ (salinity), in the estuary.

267 fDOM and $\mathrm{Cl}$ hysteresis patterns (Table 2) show consistent, anti-clockwise and clockwise response,

268 respectively, with only two low intensity storms showing changes in rotational pattern. $\mathrm{NO}_{3}$

269 hysteresis patterns are more complex, with 6 of 13 storms recording a multi-loop pattern (Figure

$2705 c$ and Figures S1-S13, supporting information). Responsiveness ( $\alpha$ ) along the rising limb did not 
271 show a significant relationship with storm runoff $\left(\mathrm{R}^{2}=0.05 ; \mathrm{p}>0.05\right)$, precipitation amount $\left(\mathrm{R}^{2}=\right.$

$2720.12 ; \mathrm{p}>0.05)$ or rising limb duration $\left(\mathrm{R}^{2}=0.07 ; \mathrm{p}>0.05\right)$ (Figure 7a-c). However, all but two

273 storms show a net concentrating response on the rising limb $\left(\bar{\alpha}_{N O 3-R L}^{+}=0.254, \mathrm{p}<0.05\right)$ and a weak

274 response on the falling limb. Relatively large storms during late summer elicited only a small

275 estuarine $\mathrm{NO}_{3}$ response, despite the occurrence of two relatively intense events (e.g. storms 6 and 9

276 relative to storm 1 and 3, Table 2). Small storms of relatively short duration (6 - 7 days) elicited in

277 multi-loop patterns. Several storms (storms 2, 6, 7 and 13) showed a small initial pulse in estuarine

$278 \mathrm{NO}_{3}$ concentration at the beginning of the rising limb.

For fDOM the responsiveness for rising limb ( $\left.\alpha_{\text {DOC-RL }}\right)$ showed an increase with duration

$280\left(\mathrm{R}^{2}=0.61 ; \mathrm{p}<0.05\right)$, total storm event discharge $\left(\mathrm{R}^{2}=0.50 ; \mathrm{p}<0.05\right)$, and total precipitation

281 amounts $\left(\mathrm{R}^{2}=0.37 ; \mathrm{p}<0.05\right)$ (Figure 8a $-\mathrm{c}$ ) with higher responsiveness for larger storms.

282 Corresponding results for falling limb of the storm-event were weaker. The hysteresis patterns of

$283 \mathrm{Cl}$ are nearly inverse those of fDOM, (Figure 5). Five storm events (storm 2, 6, 10, 12 and 13)

284 showed slightly increasing salinity along the rising limb $\left(\alpha_{\mathrm{Cl}-\mathrm{RL}}>0\right)$ (Figure S2, S6, S10,S12 and S13).

285 Estuarine fDOM for the same storms showed slight dilution with increasing DOC fluxes $\left(\alpha_{\text {DOC-RL }}<0\right)$.

286 The responsiveness patterns for $\mathrm{Cl}$ is weaker (Figure 9), but clearly the opposite of fDOM response.

\section{Discussion}

\section{$288 \quad 4.1$ Watershed Control of Estuarine DOC}

289 Past studies in watersheds have shown that constituent concentration vs. discharge

290 hysteresis occurs due to preferential delivery (source or transport limitation) of water and

291 nutrients(Camporese et al., 2014; Dusek \& Vogel, 2016; Lloyd et al., 2016; Phillips, 2003).

292 Complicated multi-loop patterns have also been attributed to complex catchment response

293 (Williams, 1989). Strong fDOM responsiveness observed with duration of rising limb of storm

294 hydrograph, increased runoff, and precipitation, and combined with a weaker response on the

295 falling limb suggests that watershed-estuary connectivity is similar to hydrologic connectivity 
296 observed between watershed, and a headwater stream or river (Kaller et al., 2015; Nippgen et al.,

297 2015). Counter to general patterns, some smaller storms resulted in increased $\mathrm{Cl}$ and dilution of

298 fDOM. Elevated influx of ocean water that counter increases in freshwater of terrestrial DOC inputs

299 can cause such a dynamic (Huang et al., 2014). Also, the changing quality of DOC exported from

300 watersheds can vary over storm events causing changes in the fDOM response (Larsen et al., 2015).

301 However these factors were not of sufficient magnitude to confound the overall coherence

302 response. Hysteresis analysis demonstrated the strong influence of watershed over estuarine DOC

303 conditions over storm-event time scales (Figure 5, Table 2).

304 DOC in both freshwaters and estuaries is derived mainly from forests and wetland (Buffam

305 et al., 2001; Creed et al., 2003). The Lamprey River sub-watershed (21\% of total watershed area)

306 consists of $82 \%$ forest and wetlands, compared to $74 \%$ for the whole watershed (Table 1).

307 Although DOC concentrations in northeastern watersheds increase with discharge, their variability

308 is smaller than the orders of magnitude variation observed in discharge (Raymond \& Saiers, 2010).

309 Indeed, the coherence between estuarine fDOM and discharge was just as strong as when using

310 DOC fluxes. Which leads us to conclude terrestrial DOC variability captured by monitoring one sub-

311 watershed was sufficient to explain the overall dynamics of DOC in the estuary, including inputs

312 from unmonitored areas. As a result, watershed DOC exports may be sufficiently well predicted by

313 commonly used, less intensive methods combining continuous flow and infrequent grab

314 measurements.

315 Factors that increase runoff from watersheds will also increase DOC exported to coastal zones.

316 This suggests that greater watershed-estuary coupling will occur in the future where more frequent

317 extreme events are predicted to occur (Hayhoe et al., 2007). More recently, reports indicate that

318 terrestrial DOC is already increasing in coastal oceans in response to changing storm patterns

319 (Balch et al., 2016). Impacts of higher fDOM in estuaries and coastal ocean include increased light 
320 attenuation and altered food webs (Traving et al., 2017). In Great Bay, eel grass has been in decline

321 in recent years (Beem \& Short, 2009). Among the hypotheses attributed to this decline is a greater

322 frequency of light limitation due to higher fDOM, similar to estuaries elsewhere (Ganju et al., 2014).

323 Which suggests the changing role of watershed DOC fluxes, along with other interacting factors (e.g.

324 suspended sediment flux and resulting turbidity) should be considered in coastal management.

\section{4.2.Conservative Behavior of Terrestrial DOC in the Estuary}

326 DOC and $\mathrm{Cl}$ coherence response is very similar in the time scale of 1-180 days Hysteresis data

327 provides more evidence of this similarity. Estuarine fDOM response is similar albeit nearly inverse

328 storm event chloride (Figures 5). The inverse pattern for $\mathrm{Cl}$ is expected when behavior is assumed

329 to be conservative because chloride in the estuary should decline during storms (since more

330 freshwater with less $\mathrm{Cl}$ than in the estuary), while fDOM in the estuary should increase (since more

331 freshwater with more DOC than in the estuary). The fact that chloride is conservative, and the

332 symmetrical and inverse behavior of fDOM over the 1-180 day time scale strongly suggests that

333 fDOM behaves in a (near-) conservative way. This behavior may be explained by the presence of

334 simultaneous sources and sinks leading to minimal turnover within the estuary (Mantoura \&

335 Woodward, 1983) or by the removal of specific components of the DOC pool (Raymond \& Spencer,

336 2014).

337 Conservative behavior of terrestrial DOC has been observed in a freshwater coastal river

338 network of New England (Wollheim et al., 2015) as well as in larger North American river

339 networks, unless there are long residence-time features in surface waters, such as large lakes or

340 reservoirs (Hanley et al., 2013). Because of relatively little transformation of terrestrial DOC in the

341 estuary, combined with the importance of transport limitation for riverine carbon transport (Bauer

342 et al., 2013) much of this DOC may eventually make its way to the coastal ocean, as observed in the

343 Gulf of Maine where its fate and consequence remain poorly understood (Balch et al., 2016). 


\section{$344 \quad 4.3$ Complex Behavior of Estuarine $\mathrm{NO}_{3}$}

345 In the Lamprey R. watershed, suburban and agricultural land-cover, a major non-point

346 source of nitrate (Wollheim et al., 2005) is $16 \%$ within this sub-watershed, and at $22 \%$ in the

347 whole watershed. Further, anthropogenic land uses are concentrated in several of the sub-

348 watersheds (Table 1 and Figure 1) creating heterogeneity of inputs relative to the hydrodynamic

349 circulation within the estuary. As a result, non-point $\mathrm{N}$ sources dominate annual loads, of which a

350 substantial portion is exported during storm events, whereas baseflow is dominated by point $\mathrm{N}$

351 sources (PREP, 2013). Over seasonal time scales, nitrate's coherence response is similar to that of

352 DOC and $\mathrm{Cl}$. This may due to watershed (baseflow) influence on estuarine conditions and the

353 predominance of point-sources over these time scales. This could also be due to the simple

354 coincidence of the periods of high and low biological activity that leads to increased sources and

355 reduced uptake occurring simultaneously in terrestrial, freshwater, and estuarine ecosystems.

356 Monitoring multiple growing seasons will allow more insight into these patterns.

357 If estuarine nitrate were to behave like in river systems, point-source dominant baseflow

358 patterns would lead to dilution during storm events (Colombo et al., 2004; Jiang et al., 2014). If

359 non-point inputs dominate, then $\mathrm{NO}_{3}$ concentrations would increase (Feinson et al., 2016). $\mathrm{NO}_{3}$

360 concentrations generally increase during storms compared to pre-storm conditions, unlike $\mathrm{Cl}$ which

361 exhibits dilution. This is an important pattern as it suggests that watershed non-point sources

362 override any dilution effect of point-source (WWTP) and $\mathrm{NO}_{3}$ uptake in watershed and estuary.

363 Further evidence to this effect can be observed in the small initial pulse of nitrate observed during

364 four events that has also been reported in the watershed (Carey et al., 2014), possibly a small

365 signature of non-point source inputs from developed areas downstream of the watershed

366 monitoring station. Thus, non-point sources are a significant control of estuarine nitrate, just as it

367 is for estuarine fDOM with watershed DOC. 
369 events because of the absence of major combined sewer overflows in this watershed (NHDES,

370 2009). However, hydrodynamics may change during freshwater pulses (Zorndt et al., 2012) so the

371 relative importance of point and non-point sources from different parts of the watershed may

372 confound the estuarine signal. This also is apparent in the coherence response, where storm-event

373 time scale coherence between watershed inputs and estuarine nitrate is greatly reduced, when

374 compared with fDOM and $\mathrm{Cl}$. This rapid dissipation of (the monitored) watershed $\mathrm{NO}_{3}$ compared to

375 terrestrial DOC signal in estuary, has been observed elsewhere (Mooney \& McClelland, 2012).

376 Unraveling causes behind this divergence in $\mathrm{NO}_{3}$ (compared to $\mathrm{DOC}$ and $\mathrm{Cl}$ ) is centrally important

377 for management, as it would suggest a need to focus on reducing point or non-point sources, or

378 alternatively, develop a better understanding the internal fate of estuarine $\mathrm{NO}_{3}$.

Estuaries are thought to be important net transformers of nitrate along the continuum from

380 terrestrial uplands to the open ocean (Galloway et al., 2003; S. Seitzinger et al., 2006). $\mathrm{Net}^{\mathrm{NO}_{3}}$

381 removal during individual storm events could occur because of assimilation by macrophytes or

382 algae, or via denitrification (Giblin et al., 2010; Kalnejais et al., 2007). The minimal response of $\mathrm{NO}_{3}$

383 observed during intense late-summer storm events may be a result of internal estuarine processes

384 resulting from warmer water (Hou et al., 2012; Ogilvie et al., 1997) (Figure 5c). The effectiveness of

385 removal of watershed inputs will vary depending on distance traveled from location of watershed

386 input and estuarine measurement location. In addition, catchment characteristics that contribute

387 to the quantity and timing of storm flows exported from watersheds may also a play a role in the

388 estuarine response. Geomorphology and basin geometry form a control on the shape and peak

389 timing of storm hydrographs (Sólyom, 2004). Whereas, storm-event constituent concentrations are

390 influenced by the spatial distribution of source material(Walling \& Webb, 1980), leading to the

391 formation of hotspots of reactivity, that play an important role in processing of nitrogen in river

392 networks (Mineau et al., 2015). It is likely that similar modifications also occur in estuaries. These 
393 observations, taken together with the coherence response suggest that nitrate is spatially complex

394 and its variability not well-predicted by the monitored watershed inputs, in contrast to terrestrial

395 DOC discussed previously.

\section{$396 \quad 5.0$ Conclusions}

The use of simultaneous watershed-estuary measurements is a potentially powerful way to

398 enhance understanding of estuarine conditions. It was exemplified here using continuous time

399 series data and application of unique analysis techniques to examine temporal signatures of

400 variability in estuarine nitrate and DOC and in the context of their watershed delivery mechanisms.

401 Watershed control of nitrate and DOC was found to be strong in the baseflow-dominant seasonal

402 and longer time scales. But strong differences were revealed in intermediate, storm-event time

403 scales, with DOC exhibiting stronger connectivity with the watershed, and nitrate showing complex

404 patterns.

405 While, the DOC behavior was attributable to the relatively homogenous distribution of

406 sources, leading to near conservative behavior over the 6-180-day time scale, a combination of

407 factors led to the complex behavior of nitrate. Among them, sporadic distribution of sources, point-

408 source dominant baseflow, non-point source dominant rapid depletion during storm events, and

409 the spatially-variable highly reactive $\mathrm{NO}_{3}$ interacting with estuarine assimilatory and dissimilatory

410 processes. Due to this homogenous nature of DOC sources, spatially limited but representative

411 monitoring of DOC would be sufficient to capture its dynamics in the estuary. However, for nitrate,

412 automated, appropriately scaled, sensor-based monitoring would be essential to meet the spatial

413 resolution necessary in this watershed, and other impaired watersheds, where human activities

414 have resulted in the formation of a heterogenous patches of sources and sinks. Such monitoring

415 programs would need to be integrated with estuarine hydrodynamic models (Ganju et al., 2016)

416 with input of high resolution data of multiple elements (here $\mathrm{DOC}, \mathrm{Cl}$, and $\mathrm{NO}_{3}$ ) to understand the

417 spatially and temporally complex patterns (e.g. Testa et al., 2014). With human and climate driven 
418 alterations of coastal ecosystems continuing to occur automated, simultaneous watershed-estuary

419 biogeochemical measurements are essential, not only to develop targeted and effective, nutrient-

420 management activities but also to understand and predict climate-driven changes to exports of

421 nutrients and carbon to the coastal waters.

\section{$422 \quad 6.0$ Acknowledgements}

423 This research was funded in part by NSF (EPS 1101245), NH Sea Grant (NOAA

424 NA100AR4170082), NH Agricultural Experiment Station and UNH ESRC's Iola Hubbard

425 Endowment for Climate Change. This is AES Scientific Contribution Number 2675 supported by the

426 USDA NIFA Hatch Project 0225006. Data underlying this work is provided with the supporting

427 information. The underlying raw data and associated metadata is provided in the supporting

428 information. Code related to the use of frequency dependent coherence is available upon request. 


\section{References}

431

432

433

434

435

436

437

438

439

440

441

442

443

444

445

446

447

448

449

450

451

452

453

454

455

456

457

458

459

460

461

462

463

464

465

466

467

468

469

Arndt, S., Vanderborght, J. P., \& Regnier, P. (2007). Diatom growth response to physical forcing in a macrotidal estuary: Coupling hydrodynamics, sediment transport, and biogeochemistry. Journal of Geophysical Research: Oceans, 112(5). https://doi.org/10.1029/2006JC003581

Balch, W., Huntington, T., Aiken, G., Drapeau, D., Bowler, B., Lubelczyk, L., \& Butler, K. (2016). Toward a quantitative and empirical dissolved organic carbon budget for the Gulf of Maine, a semienclosed shelf sea. Global Biogeochemical Cycles, 30(2), 268-292. https://doi.org/10.1002/2015GB005332

Barbier, E. B., Hacker, S. D., Kennedy, C., Koch, E. W., Stier, a. C., \& Silliman, B. R. (2011). The value of estuarine and coastal ecosystem services. Ecological Monographs, 81(2), 169-193. https://doi.org/10.1890/10-1510.1

Basu, N. B., Destouni, G., Jawitz, J. W., Thompson, S. E., Loukinova, N. V., Darracq, A., et al. (2010). Nutrient loads exported from managed catchments reveal emergent biogeochemical stationarity. Geophysical Research Letters, 37(23), 1-5. https://doi.org/10.1029/2010GL045168

Battin, T. J., Kaplan, L. a., Findlay, S., Hopkinson, C. S., Marti, E., Packman, A. I., et al. (2009). Biophysical controls on organic carbon fluxes in fluvial networks. Nature Geoscience, 2(8), 595-595. https://doi.org/10.1038/ngeo602

Bauer, J. E., Cai, W.-J., Raymond, P. A., Bianchi, T. S., Hopkinson, C. S., \& Regnier, P. A. G. (2013). The changing carbon cycle of the coastal ocean. Nature, 504(7478), 61-70. https://doi.org/10.1038/nature12857

Beem, N. T., \& Short, F. T. (2009). Subtidal eelgrass declines in the Great Bay Estuary, New Hampshire and Maine, USA. Estuaries and Coasts, 32(1), 202-205. https://doi.org/10.1007/s12237-008-9110-3

Bergamaschi, B. A., Fleck, J. A., Downing, B. D., Boss, E., Pellerin, B. A., Ganju, N. K., et al. (2012). Mercury Dynamics in a San Francisco Estuary Tidal Wetland: Assessing Dynamics Using In Situ Measurements. Estuaries and Coasts, 35(4), 1036-1048. https://doi.org/10.1007/s12237-012-9501-3

Bergamaschi, B. A., Krabbenhoft, D. P., Aiken, G. R., Patino, E., Rumbold, D. G., \& Orem, W. H. (2012). Tidally driven export of dissolved organic carbon, total mercury, and methylmercury from a mangrove-dominated estuary. Environmental Science and Technology, 46(3), 1371-1378. https://doi.org/10.1021/es2029137

Bowen, J. L., \& Valiela, I. (2008). N to Assess Coupling between Watersheds and Estuaries in Temperate and Tropical Regions. Journal of Coastal Research, 243(243), 804-813. https://doi.org/10.2112/05-0545.1

Boyer, E. W., Goodale, C. L., Jaworski, N. A., \& Howarth, R. W. (2002). Anthropogenic nitrogen sources and relationships to riverine nitrogen export in the northeastern U.S.A. Biogeochemistry, 57-58, 137-169. https://doi.org/10.1023/A:1015709302073 
Bresler, S. E. (2012). Policy recommendations for reducing reactive nitrogen from wastewater treatment in the Great Bay Estuary, NH. Environmental Science and Policy, 19-20, 69-77. https://doi.org/10.1016/j.envsci.2012.02.006

Bricker, S. B., Longstaff, B., Dennison, W., Jones, A., Boicourt, K., Wicks, C., \& Woerner, J. (2008). Effects of nutrient enrichment in the nation's estuaries: A decade of change. Harmful Algae, 8(1), 21-32. https://doi.org/10.1016/j.hal.2008.08.028

Buffam, I., Galloway, J. N., \& Blum, L. K. (2001). A storm ow/base ow comparison of dissolved organic matter concentrations and bioavailability in an Appalachian stream. Biogeochemistry, 269-306.

Camporese, M., Penna, D., Borga, M., \& Paniconi, C. (2014). A field and modeling study of nonlinear storage-discharge dynamics for an Alpine headwater catchment. Water Resources Research, 50(2), 806-822. https://doi.org/10.1002/2013WR013604

Carey, R. O. R. O., Wollheim, W. M. W. M., Mulukutla, G. K. G. K., \& Mineau, M. M. M. M. (2014). Characterizing storm-event nitrate fluxes in a fifth order suburbanizing watershed using in situ sensors. Environmental Science and Technology, 48(14), 7756-7765. https://doi.org/10.1021/es500252j

Clair, T. A., Dennis, I. F., \& Bélanger, S. (2013). Riverine nitrogen and carbon exports from the Canadian landmass to estuaries. Biogeochemistry, 115(1-3), 195-211. https://doi.org/10.1007/s10533-013-9828-2

Cloern, J. E., \& Nichols, F. H. (1985). Time scales and mechanisms of estuarine variability, a synthesis fromstudies of san francisco bay. Hydrobiologia., 12, 229-237.

Colombo, M. J., Grady, S. J., \& Trench, E. (2004). Nutrient Enrichment, Phytoplankton Algal Growth, and Estimated Rates of Instream Metabolic Processes in the Quinebaug River Basin, Connecticut , 2000 - 2001 Scientific Investigations Report 2004-5227 (pp. 2000-2001).

Creed, I. F., Sanford, S. E., Beall, F. D., Molot, L. A., \& Dillon, P. J. (2003). Cryptic wetlands: Integrating hidden wetlands in regression models of the export of dissolved organic carbon from forested landscapes. Hydrological Processes, 17(18), 3629-3648. https://doi.org/10.1002/hyp.1357

Deegan, L. a., Johnson, D. S., Warren, R. S., Peterson, B. J., Fleeger, J. W., Fagherazzi, S., \& Wollheim, W. M. (2012). Coastal eutrophication as a driver of salt marsh loss. Nature, 490(7420), 388-392. https://doi.org/10.1038/nature11533

Douglas, E. M., Asce, M., \& Fairbank, C. A. (2011). Is Precipitation in Northern New England Becoming More Extreme ? Statistical Analysis of Extreme Rainfall in Massachusetts , New Hampshire , and Maine and Updated Estimates of the 100-Year Storm. Most, 16(3), 203-218. https://doi.org/10.1061/(ASCE)HE.1943-5584.0000303.

Downing, B. D., Pellerin, B. a., Bergamaschi, B. a., Saraceno, J. F., \& Kraus, T. E. C. (2012). Seeing the light: The effects of particles, dissolved materials, and temperature on in situ measurements of DOM fluorescence in rivers and streams. Limnology and Oceanography: Methods, 10, 767-775. https://doi.org/10.4319/lom.2012.10.767 
Dusek, J., \& Vogel, T. (2016). Hillslope-storage and rainfall-amount thresholds as controls of preferential stormflow. Journal of Hydrology, 534, 590-605. https://doi.org/10.1016/j.jhydrol.2016.01.047

Evans, C., \& Davies, T. D. (1998). Causes of concentration/discharge hysteresis and its potential as a tool for analysis of episode hydrochemistry. Water Resources Research, 34(1), 129. https://doi.org/10.1029/97WR01881

Feinson, L. S., Gibs, J., Imbrigiotta, T. E., \& Garrett, J. D. (2016). Effects of Land Use and Sample Location on Nitrate-Stream Flow Hysteresis Descriptors during Storm Events. Journal of the American Water Resources Association, 52(6), 1493-1508. https://doi.org/10.1111/1752-1688.12477

Galloway, J. N., Aber, J. D., Erisman, J. W., Seitzinger, S. P., Howarth, R. W., Cowling, E. B., \& Cosby, B. J. (2003). The Nitrogen Cascade. American Institute of Biological Sciences, 53(4), 341. https://doi.org/10.1641/0006-3568(2003)053[0341:TNC]2.0.C0;2

Ganju, N. K., Miselis, J. L., \& Aretxabaleta, A. L. (2014). Physical and biogeochemical controls on light attenuation in a eutrophic, back-barrier estuary. Biogeosciences, 11(24), 7193-7205. https://doi.org/10.5194/bg-11-7193-2014

Ganju, Neil K., Brush, M. J., Rashleigh, B., Aretxabaleta, A. L., del Barrio, P., Grear, J. S., et al. (2016). Progress and Challenges in Coupled Hydrodynamic-Ecological Estuarine Modeling. Estuaries and Coasts, 39(2), 311-332. https://doi.org/10.1007/s12237015-0011-y

Giblin, A. E., Weston, N. B., Banta, G. T., Tucker, J., \& Hopkinson, C. S. (2010). The Effects of Salinity on Nitrogen Losses from an Oligohaline Estuarine Sediment. Estuaries and Coasts, 33(5), 1054-1068. https://doi.org/10.1007/s12237-010-9280-7

Gilbert, M., Needoba, J., Koch, C., Barnard, A., \& Baptista, A. (2013). Nutrient Loading and Transformations in the Columbia River Estuary Determined by High-Resolution In Situ Sensors. Estuaries and Coasts, 36(4), 708-727. https://doi.org/10.1007/s12237-013-9597-0

Godsey, S. E., Kirchner, J. W., \& Clow, D. W. (2009). Concentration-discharge relationships reflect chemostatic characteristics of US catchments. Hydrological Processes, 23(13), 1844-1864. https://doi.org/10.1002/hyp.7315

Grabowski, J., \& Peterson, C. (2007). Restoring Oyster Reefs to Recover Ecoystem Services. Ecosystem Engineers: From Plants to Protists, 405.

Hanley, K. W., Wollheim, W. M., Salisbury, J., Huntington, T., \& Aiken, G. (2013). Controls on dissolved organic carbon quantity and chemical character in temperate rivers of North America. Global Biogeochemical Cycles, 27(2), 492-504. https://doi.org/10.1002/gbc.20044

Hayhoe, K., Wake, C. P., Huntington, T. G., Luo, L., Schwartz, M. D., Sheffield, J., et al. (2007). Past and future changes in climate and hydrological indicators in the US Northeast. Climate Dynamics, 28(4), 381-407. https://doi.org/10.1007/s00382-006-0187-8 
555

556

557

558

559

560

561

562

563

564

565

566

567

568

569

570

571

572

573

574

575

576

577

578

579

580

581

582

583

584

585

586

587
Hou, L., Liu, M., Carini, S. A., \& Gardner, W. S. (2012). Transformation and fate of nitrate near the sediment-water interface of Copano Bay. Continental Shelf Research, 35, 8694. https://doi.org/10.1016/j.csr.2012.01.004

Huang, W., Hagen, S., \& Bacopoulos, P. (2014). Hydrodynamic Modeling of Hurricane Dennis Impact on Estuarine Salinity Variation in Apalachicola Bay. Journal of Coastal Research, 389-398. https://doi.org/10.2112/JCOASTRES-D-13-00022.1

Jiang, Y., Frankenberger, J. R., Bowling, L. C., \& Sun, Z. (2014). Quantification of uncertainty in estimated nitrate-N loads in agricultural watersheds. Journal of Hydrology, 519(PA), 106-116. https://doi.org/10.1016/j.jhydrol.2014.06.027

Johnson, K. S., Coletti, L. J., \& Chavez, F. P. (2006). Diel nitrate cycles observed with in situ sensors predict monthly and annual new production. Deep-Sea Research Part I: Oceanographic Research Papers, 53(3), 561-573. https://doi.org/10.1016/j.dsr.2005.12.004

Kaller, M. D., Keim, R. F., Edwards, B. L., Raynie Harlan, A., Pasco, T. E., Kelso, W. E., \& Allen Rutherford, D. (2015). Aquatic vegetation mediates the relationship between hydrologic connectivity and water quality in a managed floodplain. Hydrobiologia, 760(1), 29-41. https://doi.org/10.1007/s10750-015-2300-7

Kalnejais, L. H., Martin, W. R., Signell, R. P., \& and Michael H. Bothner. (2007). Role of Sediment Resuspension in the Remobilization of Particulate-Phase Metals from Coastal Sediments. Environmental Science \& Technology, 41(7), 2282-2288. https://doi.org/10.1021/es061770z

Kaushal, S. S., McDowell, W. H., \& Wollheim, W. M. (2014). Tracking evolution of urban biogeochemical cycles: past, present, and future. Biogeochemistry, 121(1), 1-21. https://doi.org/10.1007/s10533-014-0014-y

Kirchner, J. W., \& Neal, C. (2013). Universal fractal scaling in stream chemistry and its implications for solute transport and water quality trend detection. Proceedings of the National Academy of Sciences of the United States of America, 110(30), 12213-8. https://doi.org/10.1073/pnas.1304328110

Larsen, L., Harvey, J., Skalak, K., \& Goodman, M. (2015). Fluorescence-based source tracking of organic sediment in restored and unrestored urban streams. Limnology and Oceanography, 60(4), 1439-1461. https://doi.org/10.1002/lno.10108

Lloyd, C. E. M., Freer, J. E., Johnes, P. J., \& Collins, A. L. (2016). Using hysteresis analysis of high-resolution water quality monitoring data, including uncertainty, to infer controls on nutrient and sediment transfer in catchments. Science of the Total Environment, 543, 388-404. https://doi.org/10.1016/j.scitotenv.2015.11.028

Mantoura, R. F. C., \& Woodward, E. M. S. (1983). Conservative behaviour of riverine dissolved organic carbon in the Severn Estuary: chemical and geochemical implications. Geochimica et Cosmochimica Acta, 47(7), 1293-1309.

https://doi.org/10.1016/0016-7037(83)90069-8 
588

589

590

591

592

593

594

595

596

597

598

599

600

601

602

603

604

605

606

607

608

609

610

611

612

613

614

615

616

617

618

619

620

621

622

623

624

625

McClelland, J. W., \& Valiela, I. (1998). Linking nitrogen in estuarine producers to landderived sources. Limnology and Oceanography, 43(4), 577-585. https://doi.org/10.4319/lo.1998.43.4.0577

McKenna, J. (2004). DOC dynamics in a small temperate estuary: simultaneous addition and removal processes and implications on observed nonconservative behavior. Estuaries, 27(4), 604-616. https://doi.org/10.1007/BF02907648

Menke, W., \& Menke, J. (2012). 9 - Detecting correlations among data. In W. Menke \& J. Menke (Eds.), Environmental Data Analysis with MatLab (pp. 167-201). Boston: Elsevier. http://dx.doi.org/10.1016/B978-0-12-391886-4.00009-X

Mills, K. (2009). Ecological Trends in the Great Bay Estuary (p. 46). Durham,NH: Great Bay National Estuarine Research Reserve. Retrieved from http://greatbay.org/documents/20th-gbnerr-report.pdf

Mineau, M. M., Wollheim, W. M., \& Stewart, R. J. (2015). An index to characterize the spatial distribution of land use within watersheds and implications for river network nutrient removal and export. Geophysical Research Letters, 42(16), 6688-6695. https://doi.org/10.1002/2015GL064965

Mooney, R. F., \& McClelland, J. W. (2012). Watershed Export Events and Ecosystem Responses in the Mission-Aransas National Estuarine Research Reserve, South Texas. Estuaries and Coasts, 1-18. https://doi.org/10.1007/s12237-012-9537-4

Moran, M. A., Sheldon, W. M., \& Sheldon, J. E. (1999). Biodegradation of Riverine Dissolved Organic Carbon in Five Estuaries of the Southeastern United States. Estuaries, 22(1), 55. https://doi.org/10.2307/1352927

Morse, N. B., \& Wollheim, W. M. (2014). Climate variability masks the impacts of land use change on nutrient export in a suburbanizing watershed. Biogeochemistry, 121(1), 45-59. https://doi.org/10.1007/s10533-014-9998-6

NHDES. (2009). Combined sewer overflows in New Hampshire. An NH Department of Environmental Services Factsheet. [Online] (pp. 1-6). Concord, NH: NH Department of Environmental Services. https://doi.org/10.1016/S0273-1223(98)00802-6

Nippgen, F., McGlynn, B. L., \& Emanuel, R. E. (2015). The spatial and temporal evolution of contributing areas. Water Resources Research, 51(6), 4550-4573. https://doi.org/10.1002/2014WR016719

O'Boyle, S., Trickett, P., Partington, A., \& Murray, C. (2014). Field testing of an optical in situ nitrate sensor in three Irish estuaries. Biology and Environment, 114(1), 3318. https://doi.org/10.3318/BIOE.2014.02

Ogilvie, B., Nedwell, D. B., Harrison, R. M., Robinson, A., \& Sage, A. (1997). High nitrate, muddy estuaries as nitrogen sinks: The nitrogen budget of the River Colne estuary (United Kingdom). Marine Ecology Progress Series, 150(1-3), 217-228. https://doi.org/10.3354/meps150217 
626

627

628

629

630

631

632

633

634

635

636

637

638

639

640

641

642

643

644

645

646

647

648

649

650

651

652

653

654

655

656

657

658

659

660

661

662

663

664

Phillips, J. D. (2003). Sources of nonlinearity and complexity in geomorphic systems. Progress in Physical Geography, 27(1), 1-23. https://doi.org/10.1191/0309133303pp340ra

Pinckney, J. L., Paerl, H. W., Tester, P., \& Richardson, T. L. (2001). The role of nutrient loading and eutrophication in estuarine ecology. Environmental Health Perspectives, 109(SUPPL. 5), 699-706. https://doi.org/10.1289/ehp.01109s5699

PREP. (2013). State of Our Estuaries 2013, 48. https://doi.org/10.2217/pmt.13.66

Raymond, P. A., \& Saiers, J. E. (2010). Event controlled DOC export from forested watersheds. Biogeochemistry, 100(1), 197-209. https://doi.org/10.1007/s10533010-9416-7

Raymond, P. A., \& Spencer, R. G. M. (2014). Riverine DOM. In Biogeochemistry of Marine Dissolved Organic Matter: Second Edition (pp. 509-533). https://doi.org/10.1016/B978-0-12-405940-5.00011-X

Robins, P. E., Lewis, M. J., Freer, J., Cooper, D. M., Skinner, C. J., \& Coulthard, T. J. (2018). Improving estuary models by reducing uncertainties associated with river flows. Estuarine, Coastal and Shelf Science, 207, 63-73. https://doi.org/10.1016/j.ecss.2018.02.015

Salisbury, J., Vandemark, D., Hunt, C., Campbell, J., Jonsson, B., Mahadevan, A., et al. (2009). Episodic riverine influence on surface DIC in the coastal Gulf of Maine. Estuarine, Coastal and Shelf Science, 82(1), 108-118. https://doi.org/10.1016/j.ecss.2008.12.021

Salisbury, J. E., Vandemark, D., Hunt, C. W., Campbell, J. W., McGillis, W. R., \& McDowell, W. H. (2008). Seasonal observations of surface waters in two Gulf of Maine estuaryplume systems: Relationships between watershed attributes, optical measurements and surface pCO2. Estuarine, Coastal and Shelf Science, 77(2), 245-252. https://doi.org/10.1016/j.ecss.2007.09.033

Saraceno, J. F., Pellerin, B. A., Downing, B. D., Boss, E., Bachand, P. A. M., \& Bergamaschi, B. A. (2009). High-frequency in situ optical measurements during a storm event: Assessing relationships between dissolved organic matter, sediment concentrations, and hydrologic processes. Journal of Geophysical Research: Biogeosciences, 114(4), 1-11. https://doi.org/10.1029/2009JG000989

Schlesinger, W. H., \& Bernhardt, E. S. (2013). Chapter 6 - The Biosphere: Biogeochemical Cycling on Land. In W. H. Schlesinger \& E. S. Bernhardt (Eds.), Biogeochemistry (Third Edition) (Third Edit, pp. 173-231). Boston: Academic Press. https://doi.org/10.1016/B978-0-12-385874-0.00006-6

Seitzinger, S., Harrison, J., Bohlke, J., Bouwman, A., Lowrance, R., Peterson, B., et al. (2006). Denitrification across landscaes and waterscapes: a synthesis. Ecological Applications, 16(6), 2064-2090. https://doi.org/10.1890/10510761(2006)016[2064:DALAWA]2.0.CO;2 
Seitzinger, S. P., \& Kroeze, C. (1998). Global distribution of nitrous oxide production and $\mathrm{n}$ inputs in freshwater and coastal marine ecosystems. Global Biogeochemical Cycles, 12(1), 93-113. https://doi.org/10.1029/97GB03657

Short, F. T. (1992). The Ecology of the Great Bay Estuary, New Hampshire and Maine: an Estuarine Profile and Bibliography.

Smyth, A. R., Thompson, S. P., Siporin, K. N., Gardner, W. S., McCarthy, M. J., \& Piehler, M. F. (2013). Assessing Nitrogen Dynamics Throughout the Estuarine Landscape. Estuaries and Coasts, 36(1), 44-55. https://doi.org/10.1007/s12237-012-9554-3

Sólyom, P. B. (2004). Effect of limited storm duration on landscape evolution, drainage basin geometry, and hydrograph shapes. Journal of Geophysical Research, 109(F3), F03012. https://doi.org/10.1029/2003JF000032

Statham, P. J. (2012). Nutrients in estuaries - An overview and the potential impacts of climate change. Science of the Total Environment, 434, 213-227. https://doi.org/10.1016/j.scitotenv.2011.09.088

Swaney, D. P., Scavia, D., Howarth, R. W., \& Marino, R. M. (2008). Estuarine classification and response to nitrogen loading: Insights from simple ecological models. Estuarine, Coastal and Shelf Science, 77(2), 253-263. https://doi.org/10.1016/j.ecss.2007.09.013

Testa, J. M., Li, Y., Lee, Y. J., Li, M., Brady, D. C., Di Toro, D. M., et al. (2014). Quantifying the effects of nutrient loading on dissolved 02 cycling and hypoxia in Chesapeake Bay using a coupled hydrodynamic-biogeochemical model. Journal of Marine Systems, 139(March), 139-158. https://doi.org/10.1016/j.jmarsys.2014.05.018

Traving, S. J., Rowe, O., Jakobsen, N. M., Sørensen, H., Dinasquet, J., Stedmon, C. A., et al. (2017). The effect of increased loads of dissolved organic matter on estuarine microbial community composition and function. Frontiers in Microbiology, 8(351), 1-15. https://doi.org/10.3389/fmicb.2017.00351

Trowbridge, P. (2010). Analysis of Nitrogen Loading Reductions for Wastewater Treatment Facilities and Non-Point Sources in the Great Bay Estuary Watershed (p. 35). Concord, NH: New Hampshire Department of Environmental Services. Retrieved from http://des.nh.gov/organization/divisions/water/wmb/coastal/documents/gb_nitr o_load_analysis.pdf

Trowbridge, P, Wood, M., Underhill, J., \& Healy, D. (2014). Great Bay Nitrogen Non-Point Source Study. State of New Hampshire, Department of Environmental Services. 82pp. State of New Hampshire Department of Environmental Services. Retrieved from https://www.google.com/url?sa=t\&rct=j\&q=\&esrc=s\&source=web\&cd=1\&cad=rja\& uact=8\&ved=0ahUKEwjJ67b4j9LLAhUCdT4KHUAZB4UQFggdMAA\&url=http://des. nh.gov/organization/divisions/water/wmb/coastal/documents/gbnnpssreport.pdf\&usg=AFQjCNF1lmoLE9VP_mPIldwya1X5VmBC6w\&

Trowbridge, Phil. (2007). Hydrologic Parameters for New Hampshire's Estuaries (No. December). New Hampshire Department of Environmental Services,New Hampshire 
Estuaries Project., Univ of New Hampshire., Durham. N.H. Retrieved from https://www.ntis.gov/Search/Home/titleDetail/?abbr=PB2011109624

Valiela, I., \& Bowen, J. L. (2002). Nitrogen sources to watersheds and estuaries: Role of land cover mosaics and losses within watersheds. Environmental Pollution, 118(2), 239248. https://doi.org/10.1016/S0269-7491(01)00316-5

Vallino, J. J., Hopkinson, C. S., \& Garritt, R. H. (2005). Estimating estuarine gross production, community respiration and net ecosystem production: A nonlinear inverse technique. Ecological Modelling, 187(2-3), 281-296. https://doi.org/10.1016/j.ecolmodel.2004.10.018

Walling, D. E., \& Webb, B. W. (1980). The spatial dimension in the interpretation of stream solute behaviour. Journal of Hydrology, 47(1), 129-149. http://dx.doi.org/10.1016/0022-1694(80)90052-9

Wetz, M. S., \& Yoskowitz, D. W. (2013). An 'extreme'future for estuaries? Effects of extreme climatic events on estuarine water quality and ecology. Marine Pollution Bulletin, 69(1), 7-18.

Williams, G. P. (1989). Sediment concentration versus water discharge during single hydrologic events in rivers. Journal of Hydrology, 111(1-4), 89-106. https://doi.org/10.1016/0022-1694(89)90254-0

Wollheim, W. M., Stewart, R. J., Aiken, G. R., Butler, K. D., Morse, N. B., \& Salisbury, J. (2015). Removal of terrestrial DOC in aquatic ecosystems of a temperate river network. Geophysical Research Letters, 42(16), 6671-6679. https://doi.org/10.1002/2015GL064647

Wollheim, Wilfred M., Pellerin, B. A., Vörösmarty, C. J., \& Hopkinson, C. S. (2005). N retention in urbanizing headwater catchments. Ecosystems, 8(8), 871-884. https://doi.org/10.1007/s10021-005-0178-3

Zorndt, A. C., Schlurmann, T., \& Grabemann, I. (2012). The influence of extreme events on hydrodynamics and salinities in the Weser Estuary in the context of climate impact research. Coastal Engineering Proceedings, (33), 1-12. http://dx.doi.org/10.9753/icce.v33.currents.50 


\section{Figure and Table Captions}

Figure 1 Map of Great Bay watershed showing land use, wastewater treatment plants (WWTP), sub-watersheds, sub-estuaries and water quality monitoring stations. Refer to Table 1 for summary land-use statistics.

Figure 2. (a) Time series of estuarine fDOM and watershed DOC fluxes from the Lamprey River in 2011. fDOM is reported in quinine sulfate equivalents parts per billion units (QSE ppb). (b) Time series of estuarine nitrate concentrations and watershed nitrate fluxes. Filtered signal refers to to removal of tide dominant frequencies.

Figure 3: Discharge hydrograph for the Lamprey River, with points identifying storms. Red markers are beginning or end of storm, and green markers represent the peak flow during a storm event. Additional variations in flow observed during summer dry periods were attributed to water releases done in an upstream reservoir as part of a construction and maintenance project.

Figure 4 Frequency dependent coherence between estuarine $\mathrm{NO}_{3}$, fDOM and chloride with, (a) watershed discharge, (b) respective watershed concentrations $\left(\mathrm{NO}_{3}, \mathrm{fDOM}\right.$ and chloride), and (c) respective watershed fluxes ( $\mathrm{NO}_{3}$, DOC and chloride. Increasing time scales are from right to left with some highlighted.

Figure 5 Hysteresis patterns between estuarine concentrations and watershed fluxes for storm events between April and November 2011 (a) DOC, (b) Cl, (c) $\mathrm{NO}_{3}$. and (d) inset plot showing $\mathrm{NO}_{3}$ response to less intense storms. Storm events are indicated at the beginning of each storm as per their description in Table 2.

Figure 6 Relationship between baseflow watershed fluxes just prior to beginning of a storm event and corresponding estuarine concentration (a) $\mathrm{NO}_{3}$ (b) estuarine fDOM and watershed DOC, and (c) Chloride.

Figure 7. Relationship between estuarine responsiveness ( $\alpha$ ) for NO3 with (a) storm event duration (b) total storm runoff (c) total storm precipitation.

Figure 8. Relationship between estuarine responsiveness ( $\alpha$ ) for fDOM with (a) storm event duration (b) total storm runoff (c) total storm precipitation.

Figure 9. Relationship between estuarine responsiveness ( $\alpha$ ) for $\mathrm{Cl}$ with (a) storm event duration (b) total storm runoff (c) total storm precipitation.

Table 1: Land use statistics for the Great Bay watershed and its major sub-watersheds

Table 2. Storm characteristics and patterns between estuarine and watershed NO3, terrestrial DOC and $\mathrm{Cl}$ for 13 storm events monitored.

Table 3: Average coherence values over time scales larger than a day . 
Table 1: Land use statistics for the Great Bay watershed and its major sub-watersheds

\begin{tabular}{|c|c|c|c|c|c|c|}
\hline Watershed & $\begin{array}{l}\text { Total } \\
\text { Area } \\
\mathbf{k m}^{2}\end{array}$ & $\begin{array}{l}\text { Developed } \\
\text { Land } \\
\left(\mathrm{km}^{2}\right)(\%)\end{array}$ & $\begin{array}{l}\text { Agricultural } \\
\text { Land } \\
\left(\mathrm{km}^{2}\right)(\%)\end{array}$ & $\begin{array}{l}\text { Forests and } \\
\text { Wetlands } \\
\left(\mathrm{km}^{2}\right)(\%)\end{array}$ & $\begin{array}{l}\text { Water } \\
\left(\mathrm{km}^{2}\right)(\%)\end{array}$ & Remarks \\
\hline Great Bay & 2652.5 & $369.9(14.0)$ & $202.5(7.6)$ & $1976.6(74.5)$ & $103.4(3.9)$ & Whole watershed \\
\hline Bellamy River & 87.9 & 16.7 (19.0) & $8.7(9.8)$ & $58.2(66.2)$ & $4.4(5.0)$ & \\
\hline Cocheco River & 479.8 & $74.4(15.5)$ & $34.5(7.2)$ & $359(74.8)$ & $12(2.5)$ & \\
\hline Lamprey River & 555.0 & $55.8(10.1)$ & $32.7(5.9)$ & $456.3(82.2)$ & $10.3(1.9)$ & $\begin{array}{l}\text { Sub-watershed } \\
\text { monitored in this } \\
\text { study }\end{array}$ \\
\hline Oyster River & 79.1 & $17.7(22.4)$ & $9.1(11.5)$ & $50.5(63.9)$ & $1.8(2.3)$ & \\
\hline Salmon Falls River & 852.6 & $84.5(9.9)$ & $57.8(6.8)$ & $686.1(80.5)$ & $24.2(2.8)$ & \\
\hline $\begin{array}{l}\text { Squamscott/Exeter } \\
\text { River }\end{array}$ & 330.6 & $47.7(14.4)$ & $40.1(12.1)$ & $239(72.3)$ & $3.9(1.2)$ & \\
\hline Winnicut River & 48.1 & $14.0(29.2)$ & $5.2(10.8)$ & $28.3(58.7)$ & $0.7(1.4)$ & \\
\hline Great Bay Drainage & 70.6 & $10.6(15.0)$ & $6.7(9.5)$ & $30.3(43.0)$ & $23(32.5)$ & $\begin{array}{l}\text { Direct drainage to } \\
\text { Great Bay proper }\end{array}$ \\
\hline $\begin{array}{l}\text { Lower Piscataqua } \\
\text { Drainage }\end{array}$ & 147.4 & $48.5(32.9)$ & $7.7(5.2)$ & $67.9(46.0)$ & $23.3(15.8)$ & $\begin{array}{l}\text { Direct drainage to } \\
\text { Piscataqua River }\end{array}$ \\
\hline
\end{tabular}


Table 2. Storm characteristics and patterns between estuarine and watershed NO3, terrestrial DOC and Cl for 13 storm events monitored..

\begin{tabular}{|c|c|c|c|c|c|c|c|c|c|c|c|c|c|c|c|c|}
\hline & & & & & & Estuary & $y-f D O M$ & I Vs Water & shed DC & C fluxes & Estuary $\mathrm{N}$ & $\mathrm{O}_{3} \mathrm{Vs} . \mathrm{V}$ & Vatershed & $\mathrm{NO}_{3}$ flu & dxes & Estuary Cl \\
\hline \begin{tabular}{|c|} 
Storm \\
No
\end{tabular} & $\mid \begin{array}{c}\text { Begin } \\
\text { Date } \\
(\mathrm{mm}-\mathrm{dd})\end{array}$ & $\begin{array}{c}\text { Storm } \\
\text { Duration } \\
\text { (days) }\end{array}$ & $\begin{array}{c}\text { Mean } \\
\text { Flow } \\
\left(\mathrm{m}^{\wedge} 3 / \mathrm{s}\right)\end{array}$ & \begin{tabular}{|c|} 
Total \\
Storm Vol. \\
$(\mathrm{m} 3$ \\
$\left./ 10^{3}\right)$
\end{tabular} & \begin{tabular}{|c|} 
Total \\
Precip.c \\
$(\mathrm{mm})$
\end{tabular} & \begin{tabular}{|c|} 
Rising \\
Limb \\
fit, $\alpha^{z}$
\end{tabular} & $\begin{array}{c}\mathrm{p}- \\
\text { value }\end{array}$ & \begin{tabular}{|c|} 
Falling \\
Limb fit, \\
$\alpha^{z}$
\end{tabular} & $\begin{array}{c}\mathrm{p}- \\
\text { value }\end{array}$ & $\begin{array}{c}\text { Hyst. } \\
\text { Pattern } \\
\text { a }\end{array}$ & $\begin{array}{c}\text { Rising } \\
\text { Limb fit, } \\
\alpha^{z}\end{array}$ & $\begin{array}{c}\mathrm{p}^{-} \\
\text {value }\end{array}$ & $\begin{array}{c}\text { Falling } \\
\text { Limb fit, } \\
\alpha^{z}\end{array}$ & \begin{tabular}{|c|}
$\mathrm{p}-$ \\
value
\end{tabular} & $\begin{array}{c}\text { Hyst. } \\
\text { Pattern a }\end{array}$ & $\begin{array}{c}\text { Hyst. } \\
\text { Pattern a }\end{array}$ \\
\hline 1 & $05-14$ & 21 & 16.2 & 12614 & 95 & 0.13 & 0.000 & 0.15 & 0.000 & $\mathrm{AC}$ & 0.51 & 0.000 & -0.01 & 0.357 & $\mathrm{AC}$ & $\mathrm{C}$ \\
\hline 2 & 06-09 & 12 & 4.5 & 621 & 56 & -0.01 & \begin{tabular}{|l|}
0.087 \\
\end{tabular} & 0.15 & 0.000 & $\mathrm{AC}$ & 0.55 & 0.000 & 1.23 & 0.000 & $\mathrm{AC}$ & $\mathrm{C}$ \\
\hline 3 & $06-22$ & 14 & 6.6 & 3183 & 57 & 0.09 & 0.000 & 0.14 & 0.000 & $\mathrm{AC}$ & 0.34 & 0.000 & 0.06 & 0.000 & ML & $\mathrm{C}$ \\
\hline 4 & 08-08 & 7 & 0.8 & 186 & 23 & -0.02 & 0.051 & -0.04 & 0.000 & ML & -0.08 & 0.000 & 0.64 & \begin{tabular}{|l|}
0.000 \\
\end{tabular} & ML & ML \\
\hline 5 & $08-15$ & 9 & 1.8 & 769 & 54 & 0.00 & 0.267 & -0.07 & 0.000 & $\mathrm{AC}$ & 0.22 & 0.000 & 0.01 & 0.000 & $\mathrm{AC}$ & $\mathrm{C}$ \\
\hline 6 & $08-24$ & 13 & 5.7 & 3911 & 92 & 0.06 & 0.000 & 0.07 & 0.000 & $\mathrm{AC}$ & 0.13 & 0.000 & -0.15 & 0.000 & AC & $\mathrm{C}$ \\
\hline 7 & $09-06$ & 11 & 4.0 & 1303 & 47 & 0.11 & 0.000 & 0.09 & 0.000 & $\mathrm{AC}$ & 0.03 & 0.083 & 0.25 & 0.000 & $\mathrm{ML}$ & $\mathrm{C}$ \\
\hline 8 & $09-23$ & 6 & 3.1 & 545 & 38 & -0.04 & 0.000 & 0.21 & 0.000 & $\mathrm{Cb}^{\mathrm{b}}$ & -0.12 & 0.000 & -0.11 & 0.000 & AC & $\mathrm{AC}$ \\
\hline 9 & $09-29$ & 13 & 10.6 & 7232 & 95 & 0.40 & 0.000 & 0.00 & 0.294 & $\mathrm{AC}$ & 0.13 & 0.000 & 0.17 & 0.000 & ML & $\mathrm{C}$ \\
\hline 10 & $10-13$ & 6 & 11.5 & 2778 & 56 & -0.02 & 0.000 & -0.28 & 0.000 & $\mathrm{AC}$ & 0.41 & 0.000 & 0.01 & 0.231 & ML & $\mathrm{C}$ \\
\hline 11 & $10-19$ & 8 & 13.1 & 3507 & 67 & 0.01 & $|0.057|$ & 0.05 & 0.000 & AC & 0.01 & 0.108 & -0.13 & 0.000 & AC & $\mathrm{C}$ \\
\hline 12 & $10-27$ & 14 & 15.1 & 7011 & 58 & -0.02 & 0.000 & 0.22 & 0.000 & $\mathrm{AC}$ & 0.11 & 0.000 & 0.29 & 0.000 & ML & $\mathrm{C}$ \\
\hline 13 & 11-09 & 13 & 15.9 & 5751 & 69 & -0.03 & 0.004 & NA & 0.000 & $\mathrm{NA}^{\mathrm{c}}$ & 0.10 & 0.000 & NA & 0.000 & NA & NA \\
\hline
\end{tabular}

Notes Hysteresis Patterns (Hyst.Pattern) : AC- Anti-Clockwise , C-Clockwise, ML-Multi-Loop.

z- fit parameter for equation $\mathrm{P}=\mathrm{b}^{*} \mathrm{~F}^{\alpha}$

NA-Not Available, cprecipitation recorded at nearby National Weather Service Station in Durham, $\mathrm{NH}$ 
Table 3: Average coherence values over time scales larger than a day.

\begin{tabular}{|l|l|l|l|l|l|l|l|l|}
\hline & & \multicolumn{7}{|c|}{ Watershed Variable } \\
\hline \multirow{3}{*}{$\begin{array}{l}\text { Estuarine } \\
\text { Constituent }\end{array}$} & & $\mathbf{Q}$ & $\mathbf{N O}_{3}$ & DOC & $\mathbf{C l}$ & $\begin{array}{l}\mathbf{N O}_{3} \\
\text { flux }\end{array}$ & $\begin{array}{l}\text { DOC } \\
\text { flux }\end{array}$ & Cl flux \\
\cline { 2 - 10 } & $\mathrm{NO}_{3}$ & 0.21 & 0.049 & & & 0.133 & & \\
\cline { 2 - 10 } & $\mathbf{f D O M}$ & 0.217 & & 0.087 & & & 0.208 & \\
\cline { 2 - 9 } & $\mathbf{C l}$ & 0.171 & & & 0.107 & & & 0.157 \\
\hline
\end{tabular}






Figure 1: Map of Great Bay watershed showing land use, wastewater treatment plants (WWTP), sub-watersheds, sub-estuaries and water quality monitoring stations. Refer to Table 1 for summary land-use statistics. 

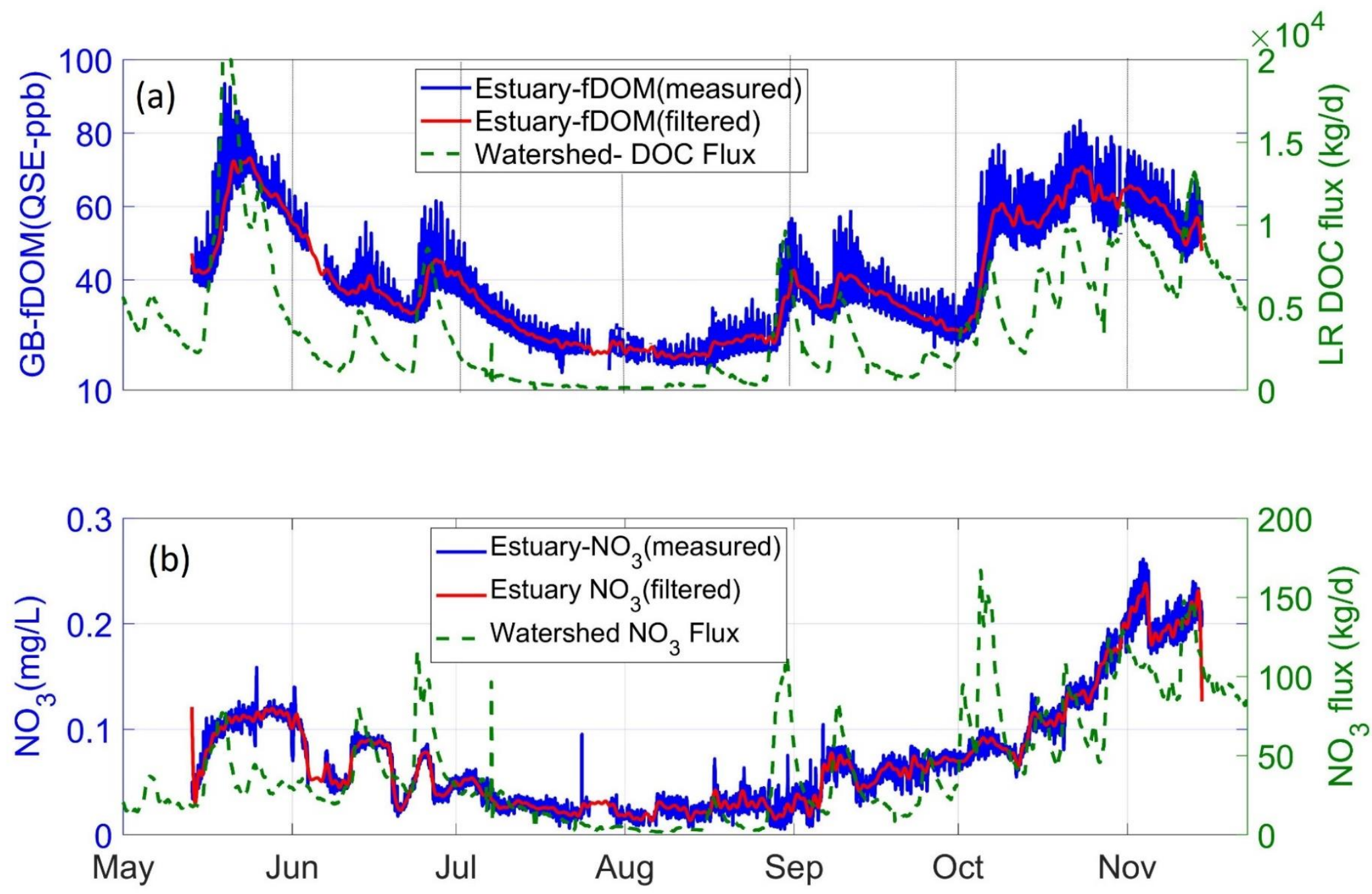

Figure 2: (a) Time series of estuarine fDOM and watershed DOC fluxes from the Lamprey River in 2011. fDOM is reported in quinine sulfate equivalents parts per billion units (QSE ppb). (b) Time series of estuarine nitrate concentrations and watershed nitrate fluxes. Filtered signal refers to to removal of tide dominant frequencies. 




Figure 3: Discharge hydrograph for the Lamprey River, with points identifying storms. Red markers are beginning or end of storm, and green markers represent the peak flow during a storm event. Additional variations in flow observed during summer dry periods were attributed to water releases done in an upstream reservoir as part of a construction and maintenance project. 


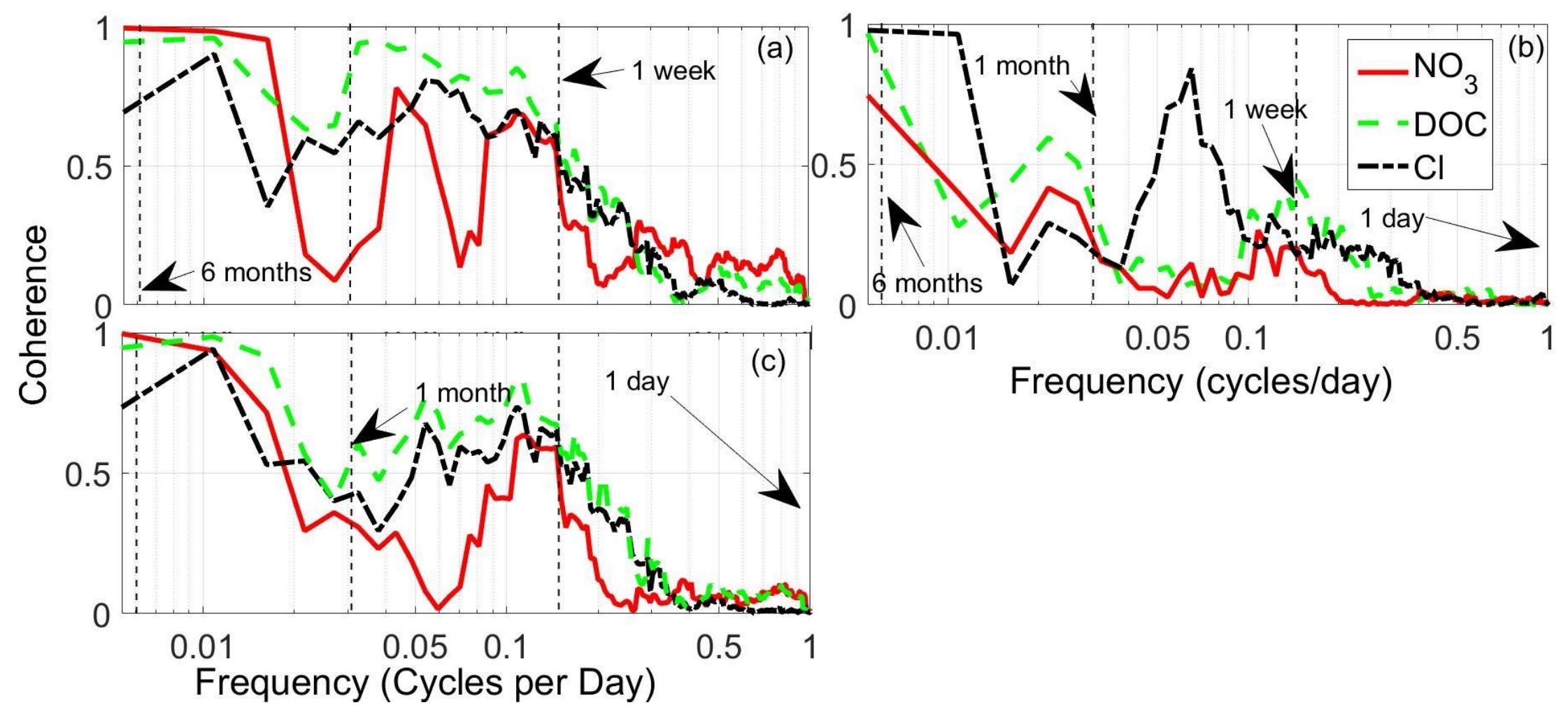

Figure 4: Frequency dependent coherence between estuarine $\mathrm{NO}_{3}, \mathrm{fDOM}$ and chloride with, (a) watershed discharge, (b) respective watershed concentrations ( $\mathrm{NO}_{3}$, fDOM and chloride), and (c) respective watershed fluxes ( $\mathrm{NO}_{3}$, $\mathrm{DOC}$ and chloride. Increasing time scales are from right to left with some highlighted. 

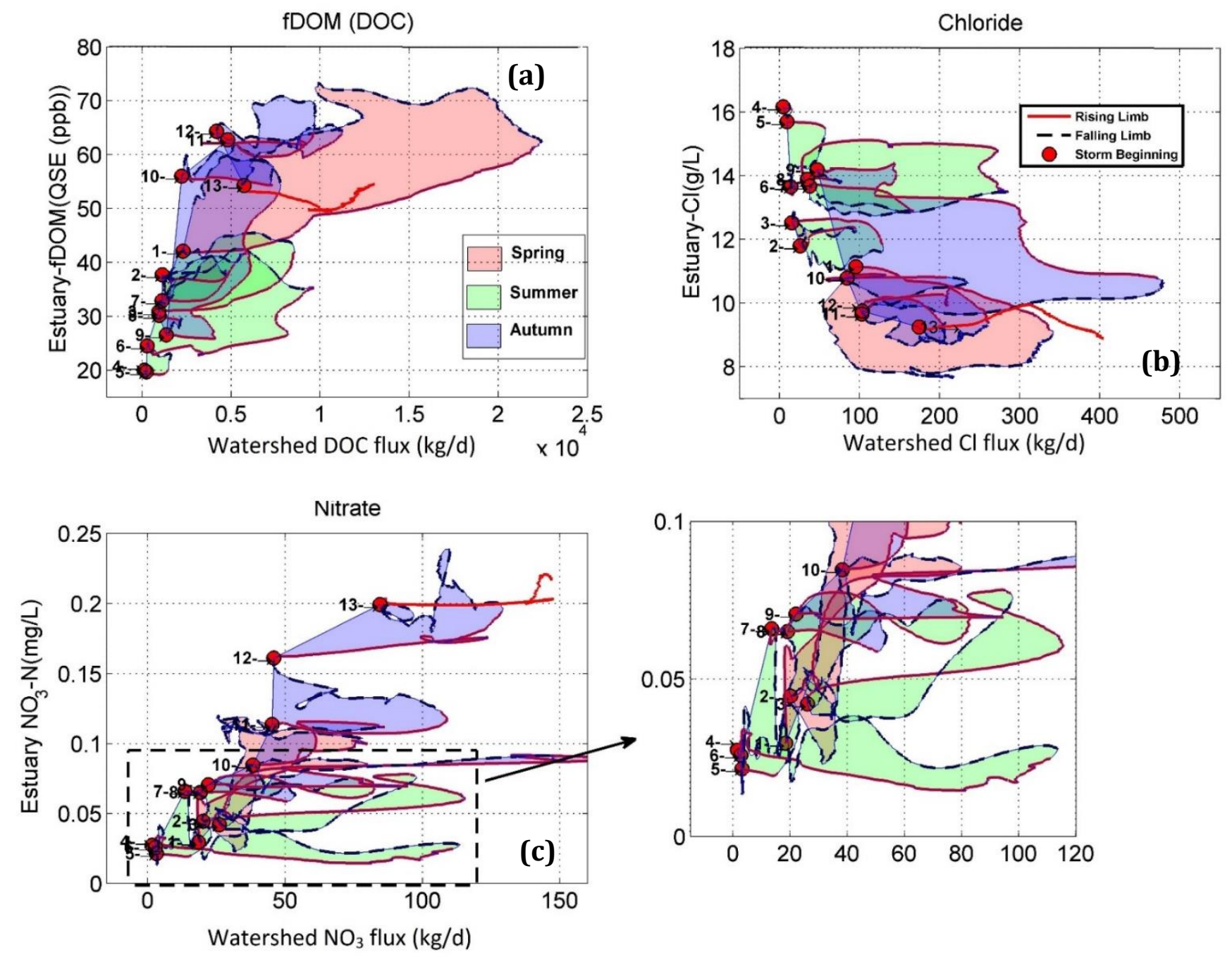

Figure 5: Hysteresis patterns between estuarine concentrations and watershed fluxes for storm events between April and November 2011 (a) DOC, (b) Cl, (c) $\mathrm{NO}_{3}$. and (d) inset plot showing $\mathrm{NO}_{3}$ response to less intense storms. Storm events are indicated at the beginning of each storm as per their description in Table 2. 

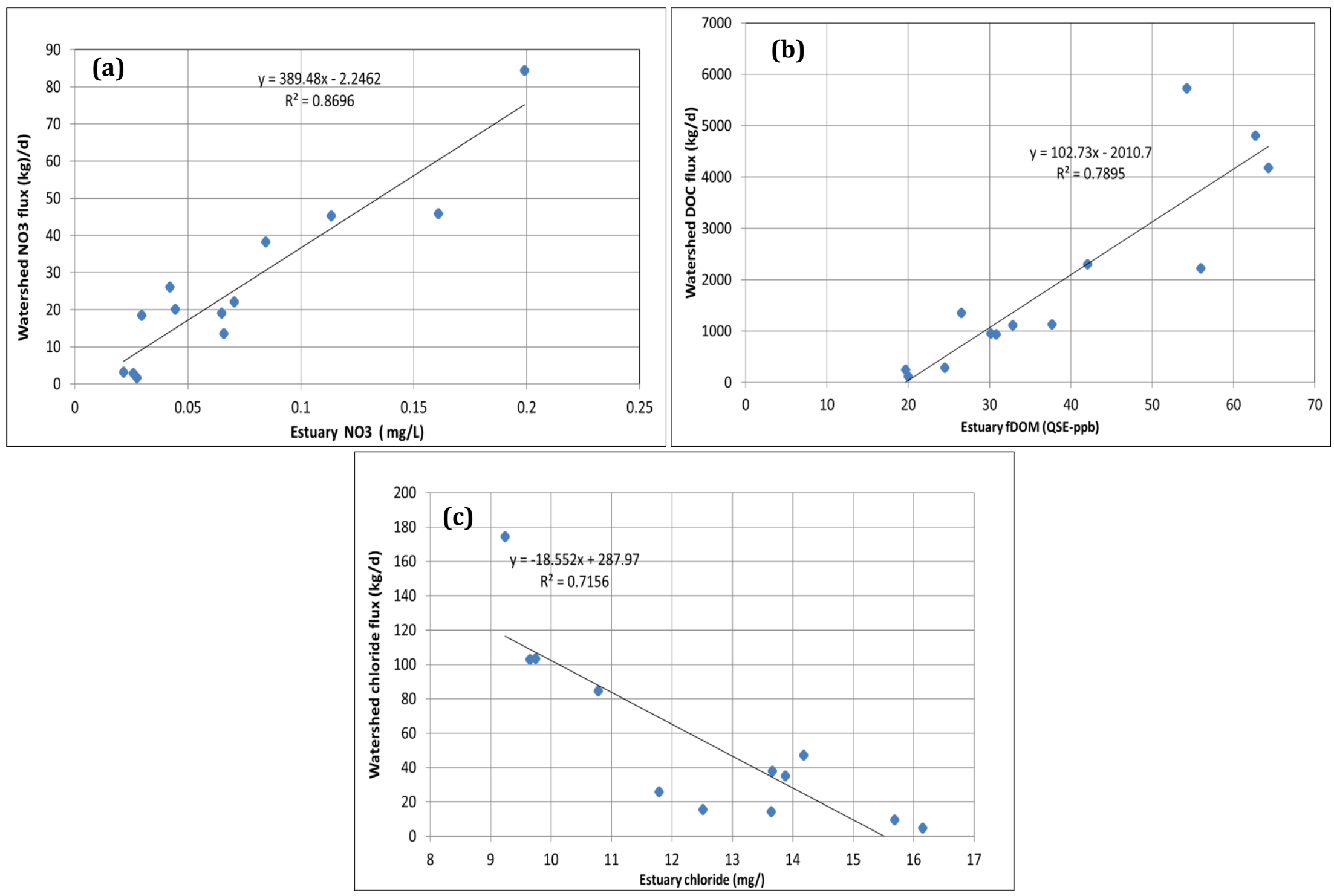

Figure 6 Relationship between baseflow watershed fluxes just prior to beginning of a storm event and corresponding estuarine concentration (a) $\mathrm{NO}_{3}$ (b) estuarine fDOM and watershed DOC, and (c) chloride. 

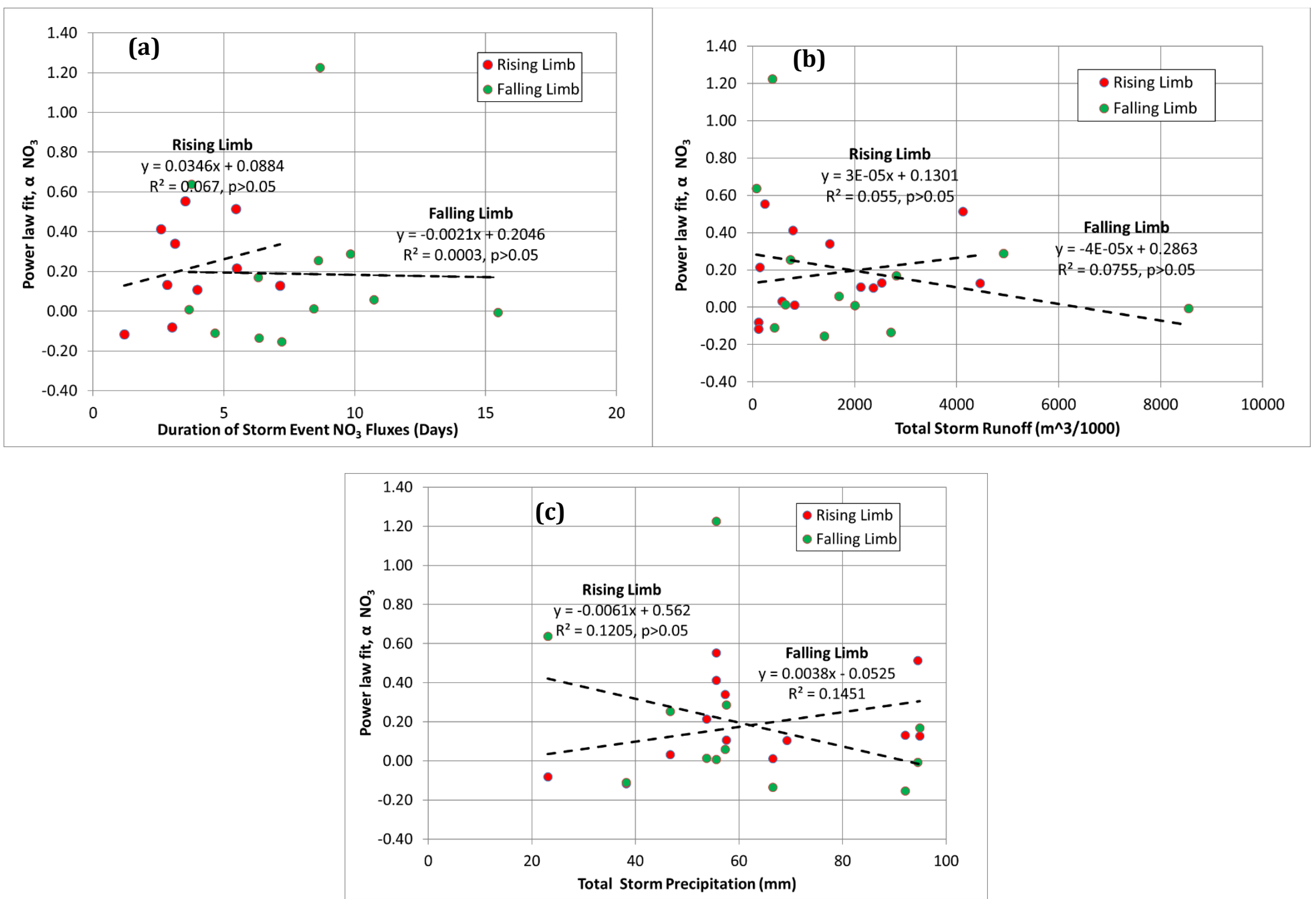

Figure 7. Relationship between estuarine responsiveness $(\alpha)$ for $\mathrm{NO}_{3}$ with (a) storm event duration (b) total storm runoff (c) total storm precipitation. 

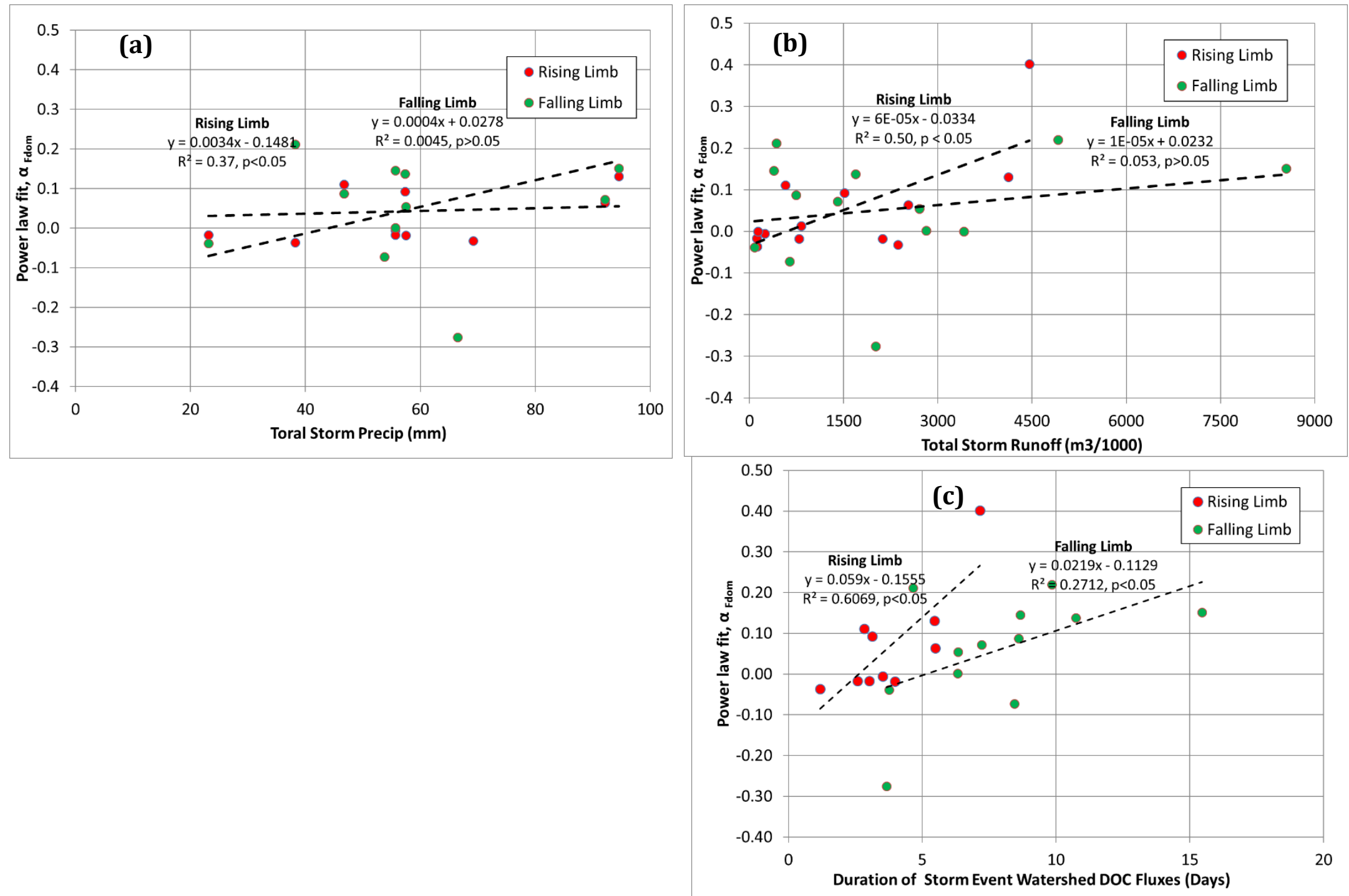

Figure 8. Relationship between estuarine responsiveness ( $\alpha$ ) for fDOM with (a) storm event duration (b) total storm runoff (c) total storm precipitation 

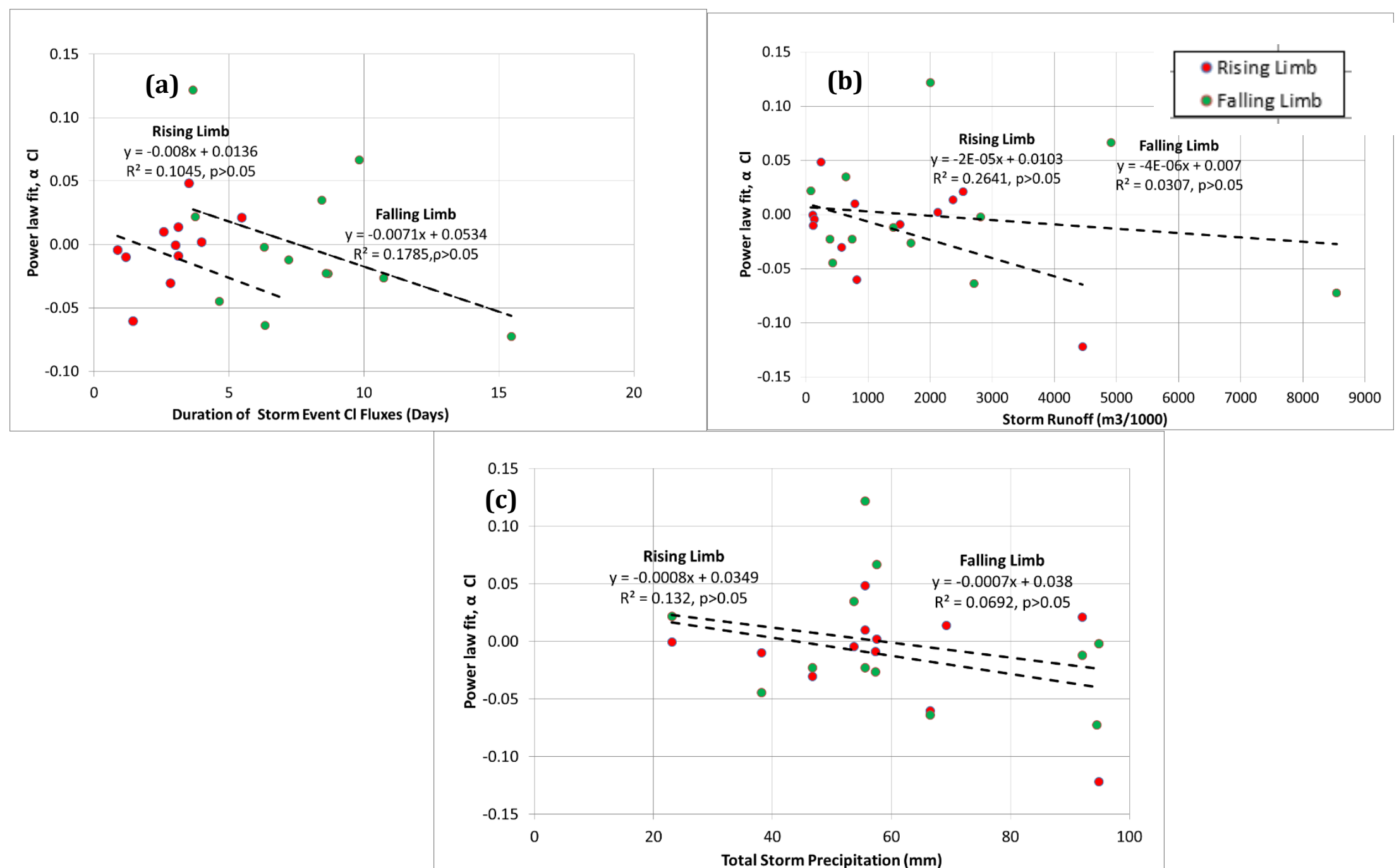

Figure 9. Relationship between estuarine responsiveness $(\alpha)$ for $\mathrm{Cl}$ with (a) storm event duration (b) total storm runoff (c) total storm precipitation. 
Supporting Information for

High frequency concurrent measurements in watershed and impaired estuary reveal coupled DOC and decoupled nitrate dynamics.

Gopal K. Mulukutla ${ }^{1}$, Wilfred M.Wollheim ${ }^{1,2}$, Joseph E. Salisbury³, Richard 0. Carey ${ }^{1,2}$, Thomas K.Gregory ${ }^{3}$ and William H. McDowell²



\section{Supporting Information Content}

Text S1 to S2

Table S1

Figures S1 to S13

Dataset file (csv file)

Dataset Metadata file (text file) 


\section{$31 \quad$ Introduction}

32 This document describes residence time estimates of the Great Bay estuary, data pre-processing

33 performed to determine lag in time series.

Table1 provides information on

- Lag measured between storm event watershed DOC fluxes and estuarine fDOM

Figures S1-S13 provide information on

- Individual storm event hysteresis response of estuarine $\mathrm{fDOM}, \mathrm{Cl}$ and $\mathrm{NO}_{3}$ to respective watershed fluxes 
57 There are various ways to characterize the tide driven removal of water and constituents from an 58 estuary.

(a) Flushing time is the time taken to remove a constituent by a pre-determined factor from a region of the estuary (Aikman \& Lanerolle, 2005; Bilgili et al., 2005) used a numerical circulation model to determine the time taken for a $63 \%$ reduction in a conservative tracer from each sub-estuary in the system. They found that with river inputs at average annual rates the flushing time was 9.2 days for the Great Bay sub-estuary, as opposed to 29.1 days for the estuarine system as a whole.

(b) Residence time is the time taken by a parcel of water to be removed from the boundaries of a specific region (Aikman \& Lanerolle, 2005; Bilgili et al., 2005)estimated that it took 19.6 days for a water parcel to exit the Great Bay sub-estuary with rivers inputs at average annual conditions.

\section{Text S2 Lag in time series}

The application of a commonly used method to determine lag ( cross correlation)(Menke \& Menke, 2012)) did not yield consistent results for nine of the thirteen storm events (see e.g. Table

S1). We attribute this to be largely due to "noisiness" in estuarine time series data, an artifact of the filtering procedure applied in removing tidal frequencies. Thus, we did not correct our data for lag. However, this does not affect the results of coherence analysis, as all the frequencies within the signal are considered in the analysis, and results are in frequency domain.

The lack of lag correction may affect the "power-law" analysis of storm event time series (results of watershed-estuary coupling in storm event time scales). We determined two areas where this could affect the results - (a) lag in storm event time series may result incorrect input of rising limb or falling limb data., and (b) lack of alignment in peaks (e.g. between watershed fluxes and estuarine concentrations) may result in increased uncertainty in determination of estuarine 
81 responsiveness $(\alpha)$. Based on data from four of the thirteen storm event, the length of lag as a

82 fraction of the total duration of the storm event was small (Table S1). This suggests that error

83 associated with (a) will be minimal and for (b) it will not affect the overall weight of the results.

84 Characterization of the uncertainty related to the lack of lag correction will require the collection of

85 data for more storm events.

86

87

88 Table S1: Lag measured between storm event watershed DOC fluxes and estuarine fDOM

89

\begin{tabular}{|c|c|c|}
\hline $\begin{array}{c}\text { Storm Duration } \\
\text { (days) }\end{array}$ & $\begin{array}{c}\text { Lag } \\
\text { (days) }\end{array}$ & $\begin{array}{c}\text { Lag as a fraction } \\
\text { of storm } \\
\text { duration (\%) }\end{array}$ \\
\hline 20.9 & 1.3 & 6.3 \\
\hline 12.2 & - & - \\
\hline 13.9 & 0.9 & 6.3 \\
\hline 6.8 & - & - \\
\hline 9.3 & - & - \\
\hline 12.7 & 1.4 & 11.5 \\
\hline 11.4 & - & - \\
\hline 5.8 & - & - \\
\hline 13.5 & 1.0 & 7.4 \\
\hline 6.3 & - & - \\
\hline 7.8 & - & - \\
\hline 13.8 & - & - \\
\hline 13.1 & - & - \\
\hline & & \\
\hline
\end{tabular}

91

92

93

94 


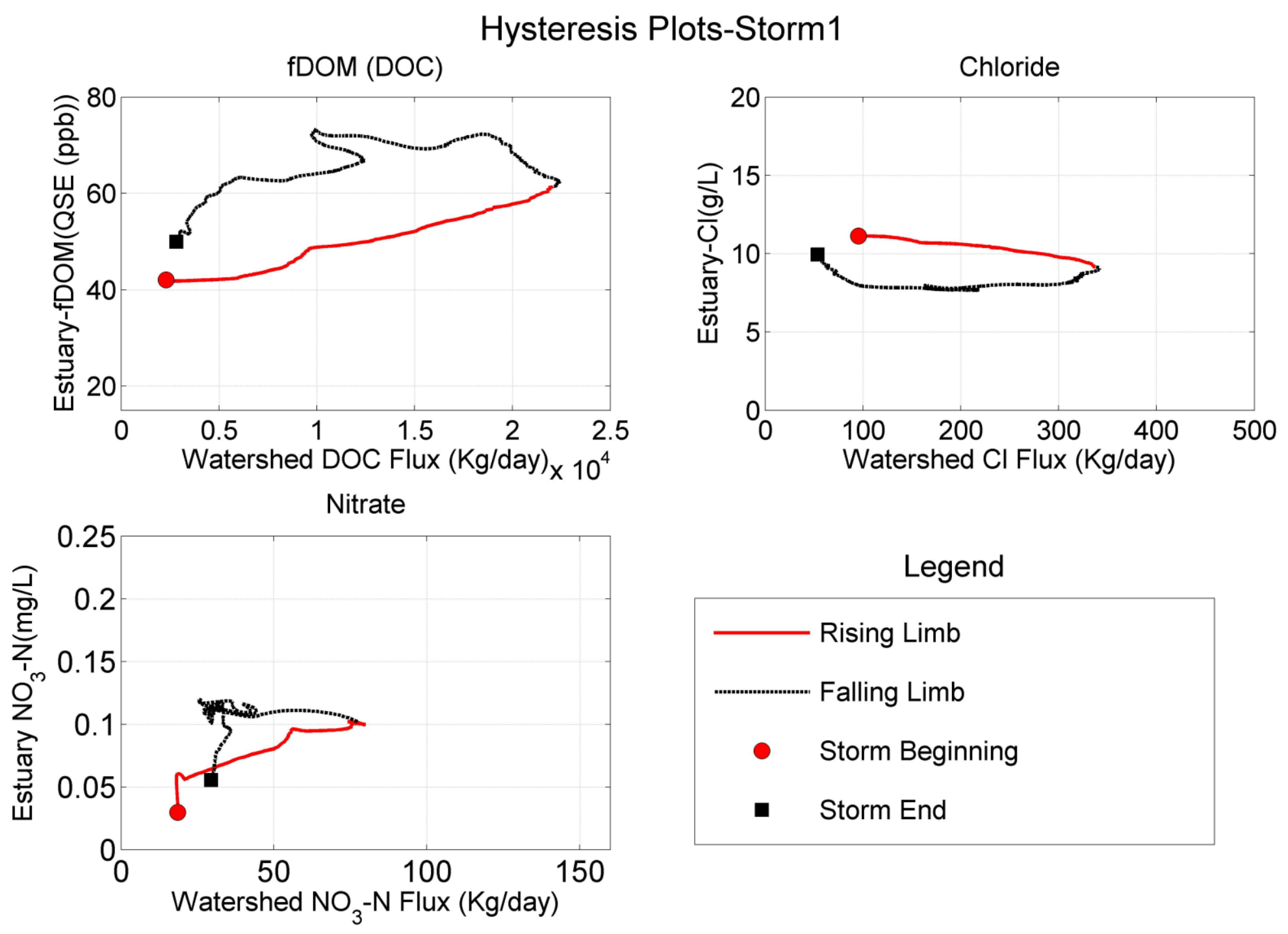

Figure S1 Hysteresis Pattern for one storm event, watershed variable ( fluxes of DOC, NO3, and Cl) Vs. Estuarine variable ( fDOM, NO3, Cl) 


\section{Hysteresis Plots-Storm2}
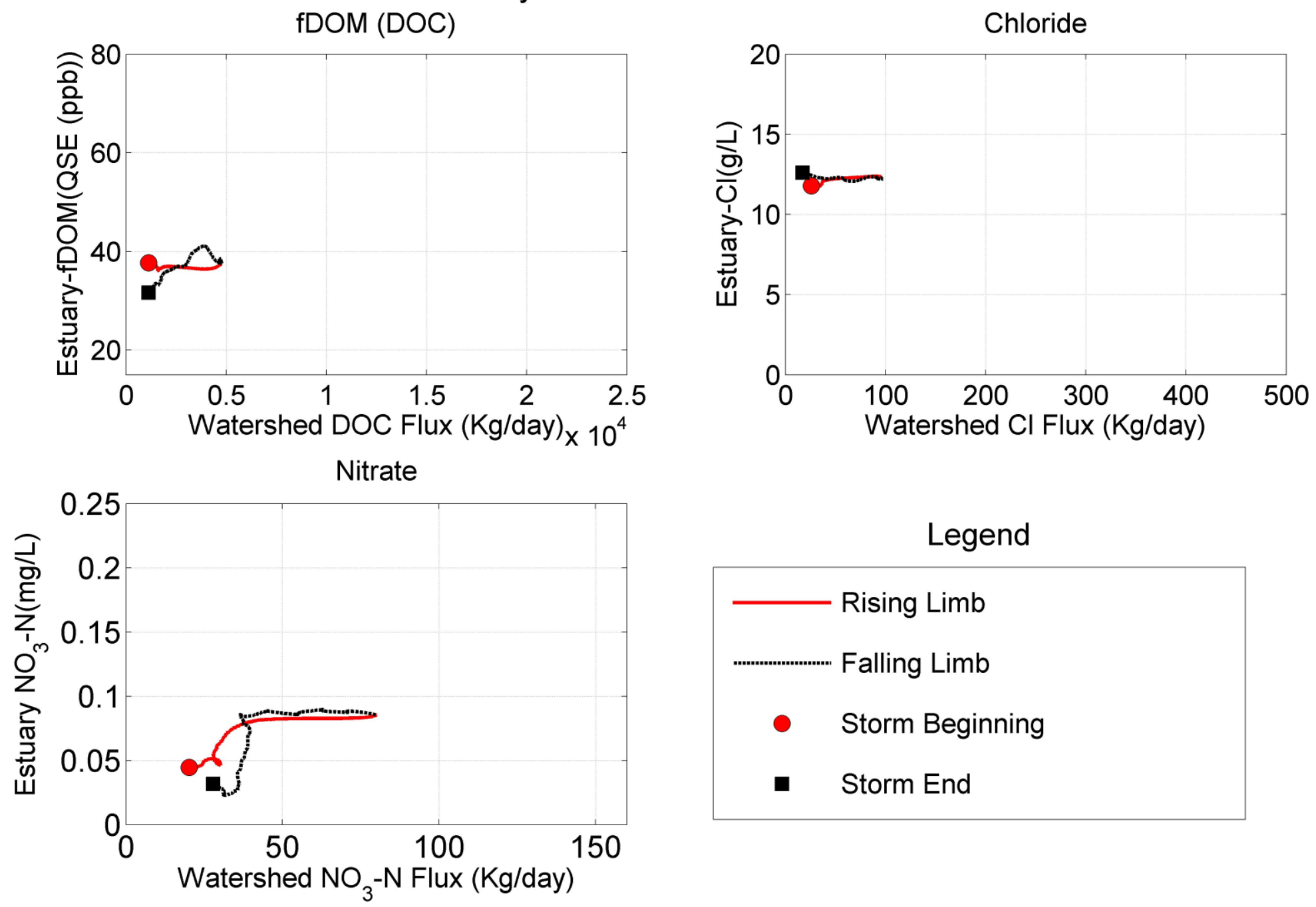

Figure S2 Hysteresis Pattern for one storm event, watershed variable ( fluxes of DOC, NO3-N, and Cl) Vs. Estuarine variable ( fDOM, NO3, $\mathrm{Cl}$ ) 


\section{Hysteresis Plots-Storm3}
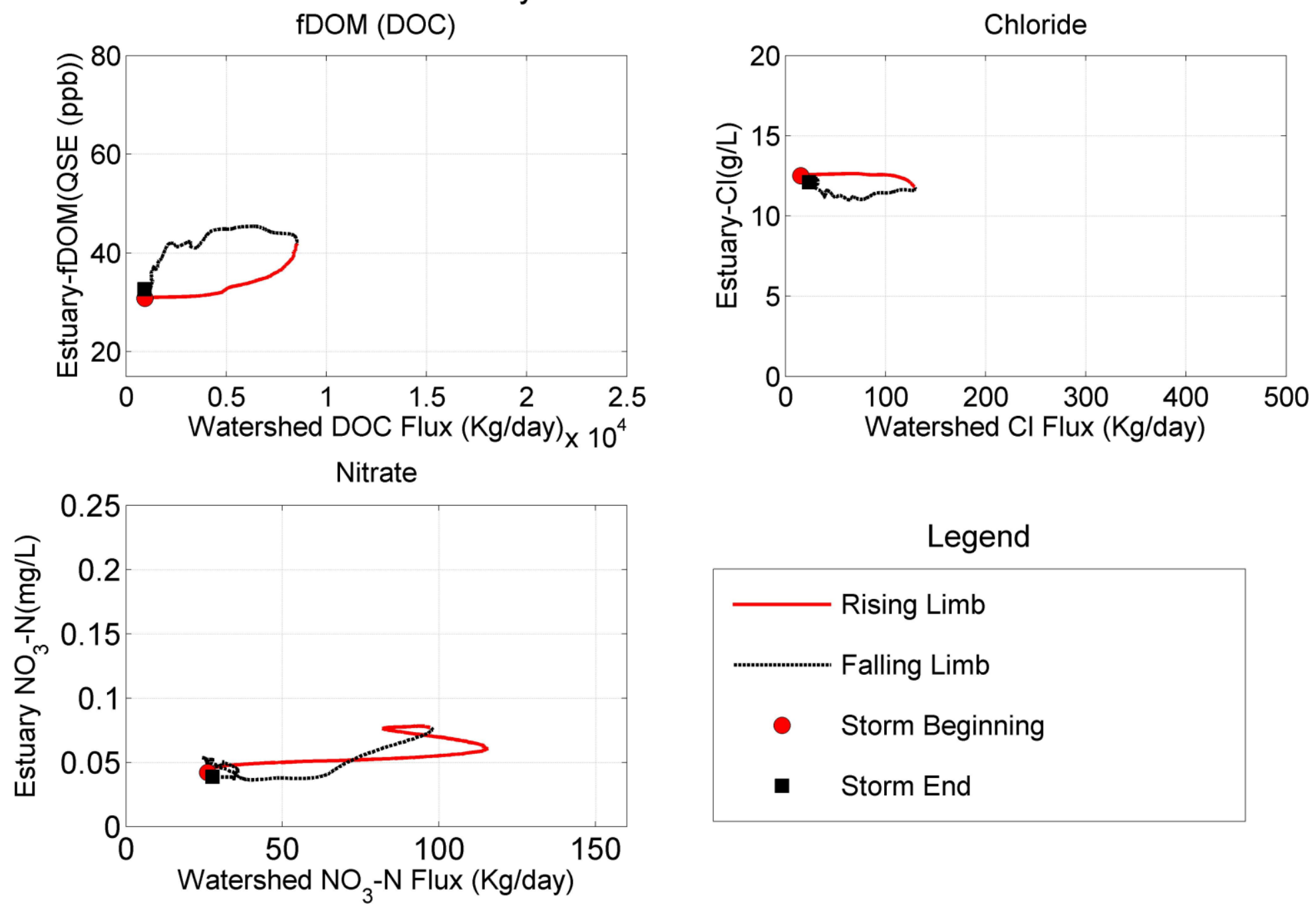

Figure S3 Hysteresis Pattern for one storm event, watershed variable ( fluxes of DOC, $\mathrm{NO}_{3}$, and $\mathrm{Cl}$ ) Vs. Estuarine variable ( $\mathrm{fDOM}, \mathrm{NO}$, $\mathrm{Cl}$ ) 


\section{Hysteresis Plots-Storm4}


Figure S4 Hysteresis Pattern for one storm event, watershed variable ( fluxes of $\mathrm{DOC}, \mathrm{NO}_{3}$, and $\mathrm{Cl}$ ) Vs. Estuarine variable ( $\mathrm{fDOM}, \mathrm{NO}$, $\mathrm{Cl}$ ) 


\section{Hysteresis Plots-Storm5}


Figure S5 Hysteresis Pattern for one storm event, watershed variable ( fluxes of $\mathrm{DOC}, \mathrm{NO}_{3}$, and $\mathrm{Cl}$ ) Vs. Estuarine variable ( $\mathrm{fDOM}, \mathrm{NO}$, $\mathrm{Cl}$ ) 


\section{Hysteresis Plots-Storm6}


Figure S6 Hysteresis Pattern for one storm event, watershed variable ( fluxes of $\mathrm{DOC}^{\mathrm{NO}} \mathrm{N}_{3}$, and $\mathrm{Cl}$ ) Vs. Estuarine variable ( $\mathrm{fDOM}$, $\mathrm{NO}$, $\mathrm{Cl}$ ) 


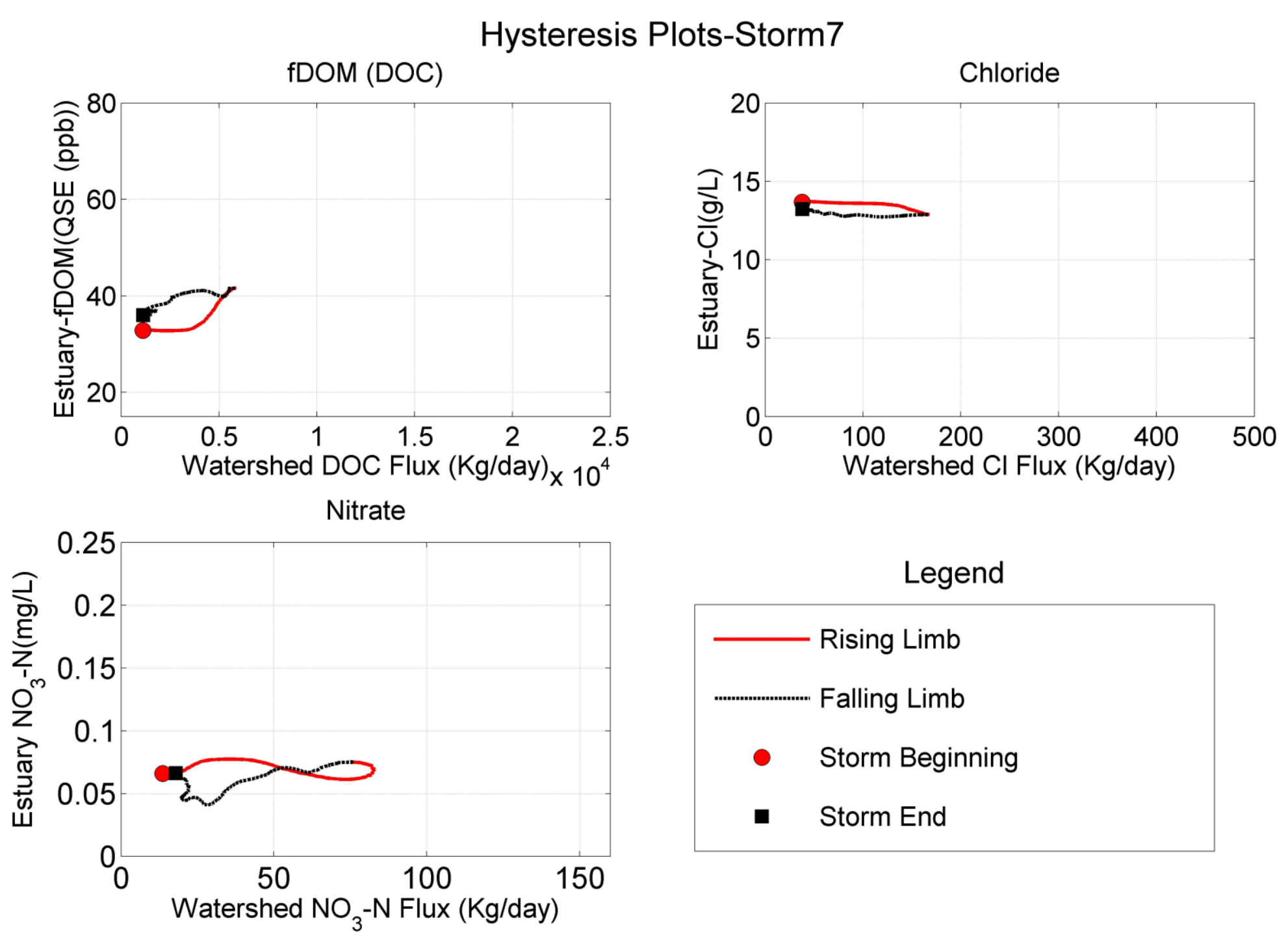

Figure S7 Hysteresis Pattern for one storm event, watershed variable ( fluxes of DOC, $\mathrm{NO}_{3}$, and Cl) Vs. Estuarine variable ( $\mathrm{fDOM}, \mathrm{NO}$, $\mathrm{Cl}$ ) 


\section{Hysteresis Plots-Storm8}
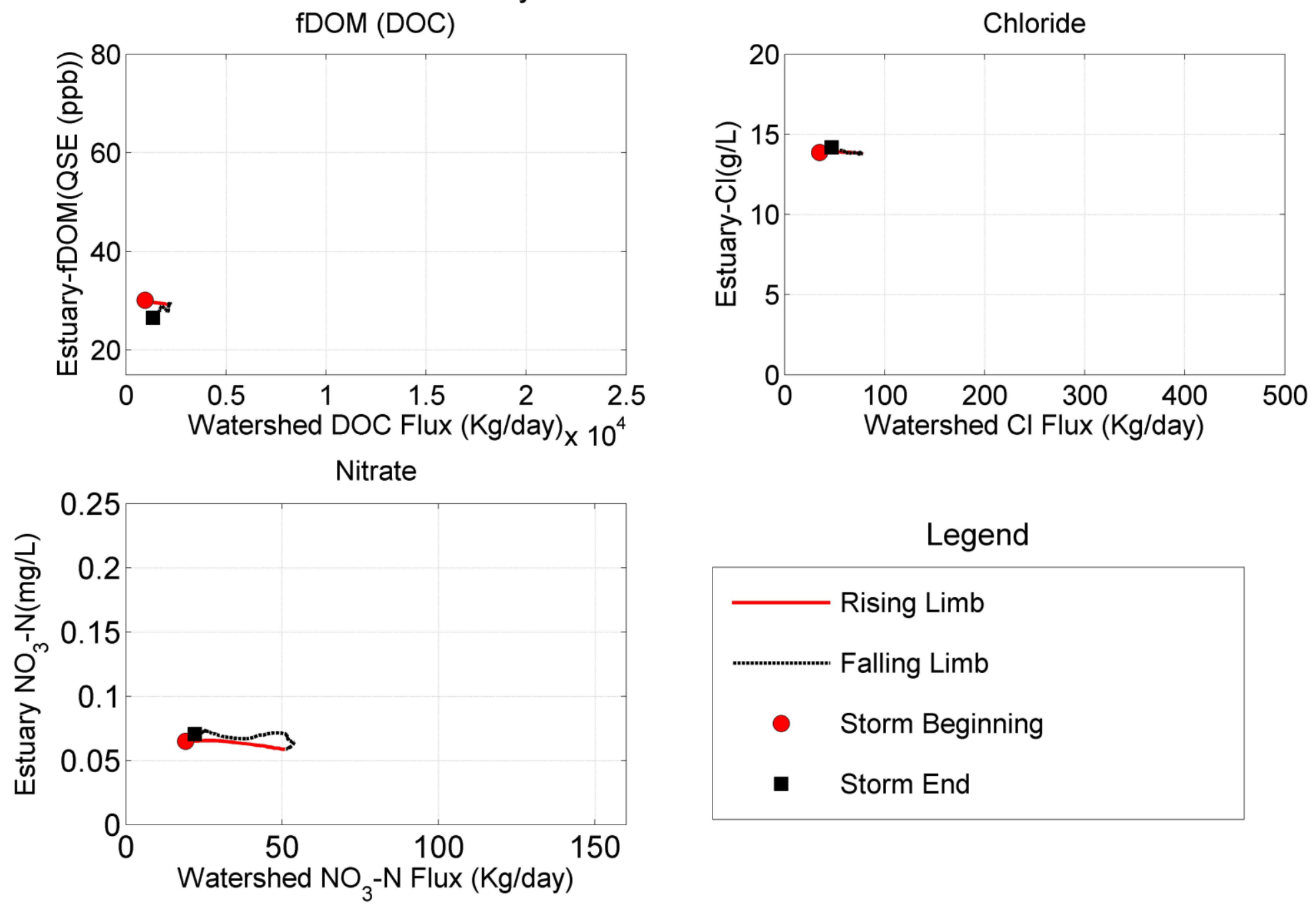

Figure S8 Hysteresis Pattern for one storm event, watershed variable ( fluxes of DOC, $\mathrm{NO}_{3}$, and $\mathrm{Cl}$ ) Vs. Estuarine variable ( $\mathrm{fDOM}, \mathrm{NO} 3, \mathrm{Cl}$ ) 


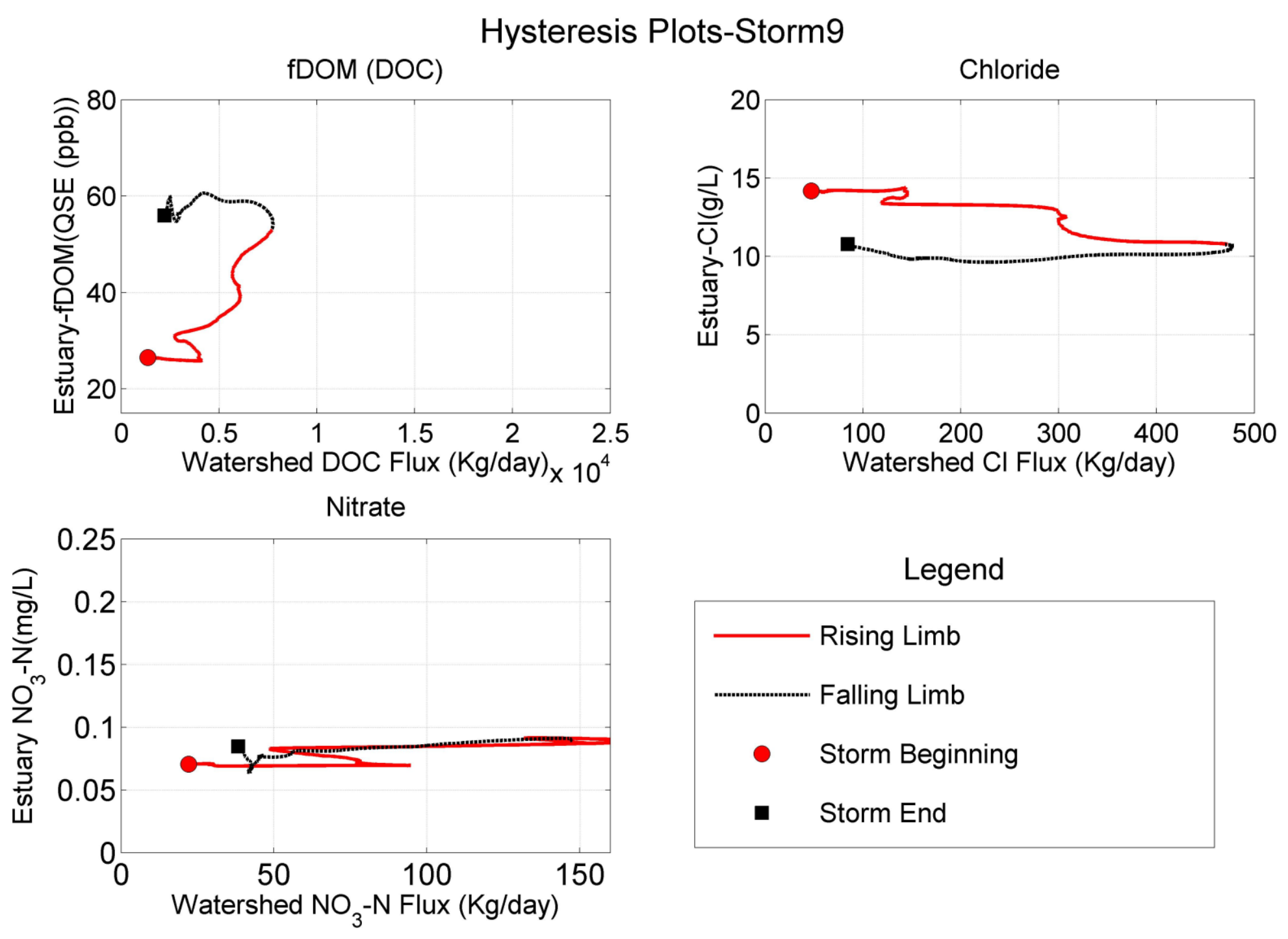

Figure S9 Hysteresis Pattern for one storm event, watershed variable ( fluxes of DOC, $\mathrm{NO}_{3}$, and $\mathrm{Cl}$ ) Vs. Estuarine variable ( $\mathrm{fDOM}, \mathrm{NO} 3, \mathrm{Cl}$ ) 


\section{Hysteresis Plots-Storm10}


Figure S10 Hysteresis Pattern for one storm event, watershed variable ( fluxes of $\mathrm{DOC} \mathrm{NO}_{3}$, and $\mathrm{Cl}$ ) Vs. Estuarine variable ( $\mathrm{fDOM}, \mathrm{NO}$, $\mathrm{Cl}$ 


\section{Hysteresis Plots-Storm11}
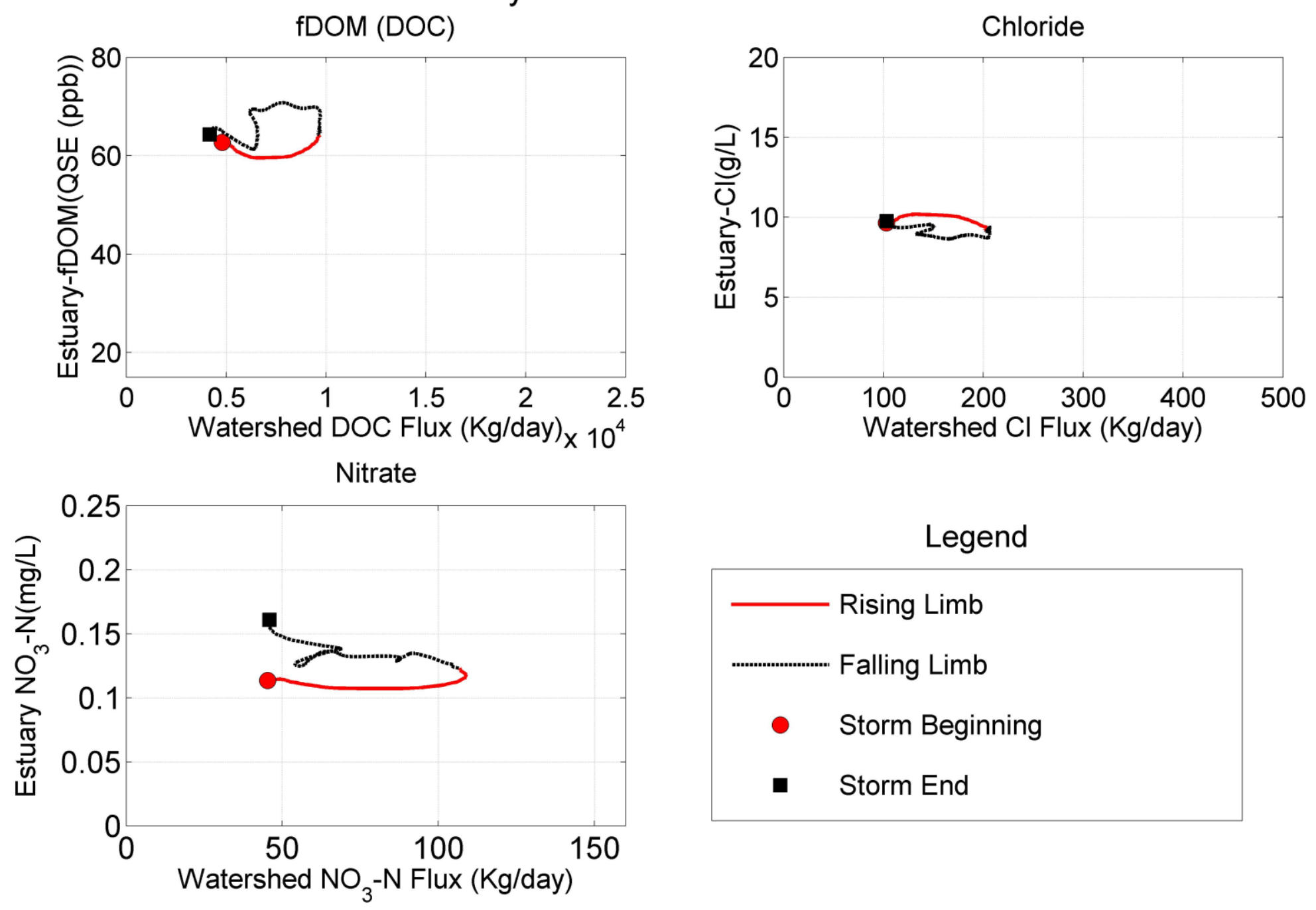

Figure S11 Hysteresis Pattern for one storm event, watershed variable ( fluxes of $\mathrm{DOC}, \mathrm{NO}_{3}$, and $\mathrm{Cl}$ ) Vs. Estuarine variable ( $\mathrm{fDOM}, \mathrm{NO}_{3}$, $\mathrm{Cl}$ ) 


\section{Hysteresis Plots-Storm12}


Figure S12 Hysteresis Pattern for one storm event, watershed variable ( fluxes of $\mathrm{DOC}, \mathrm{NO}_{3}$, and $\mathrm{Cl}$ ) Vs. Estuarine variable ( $\mathrm{fDOM}$, $\mathrm{NO}$, $\mathrm{Cl}$ ). Only rising limb data is shown here. 


\section{Hysteresis Plots-Storm13}
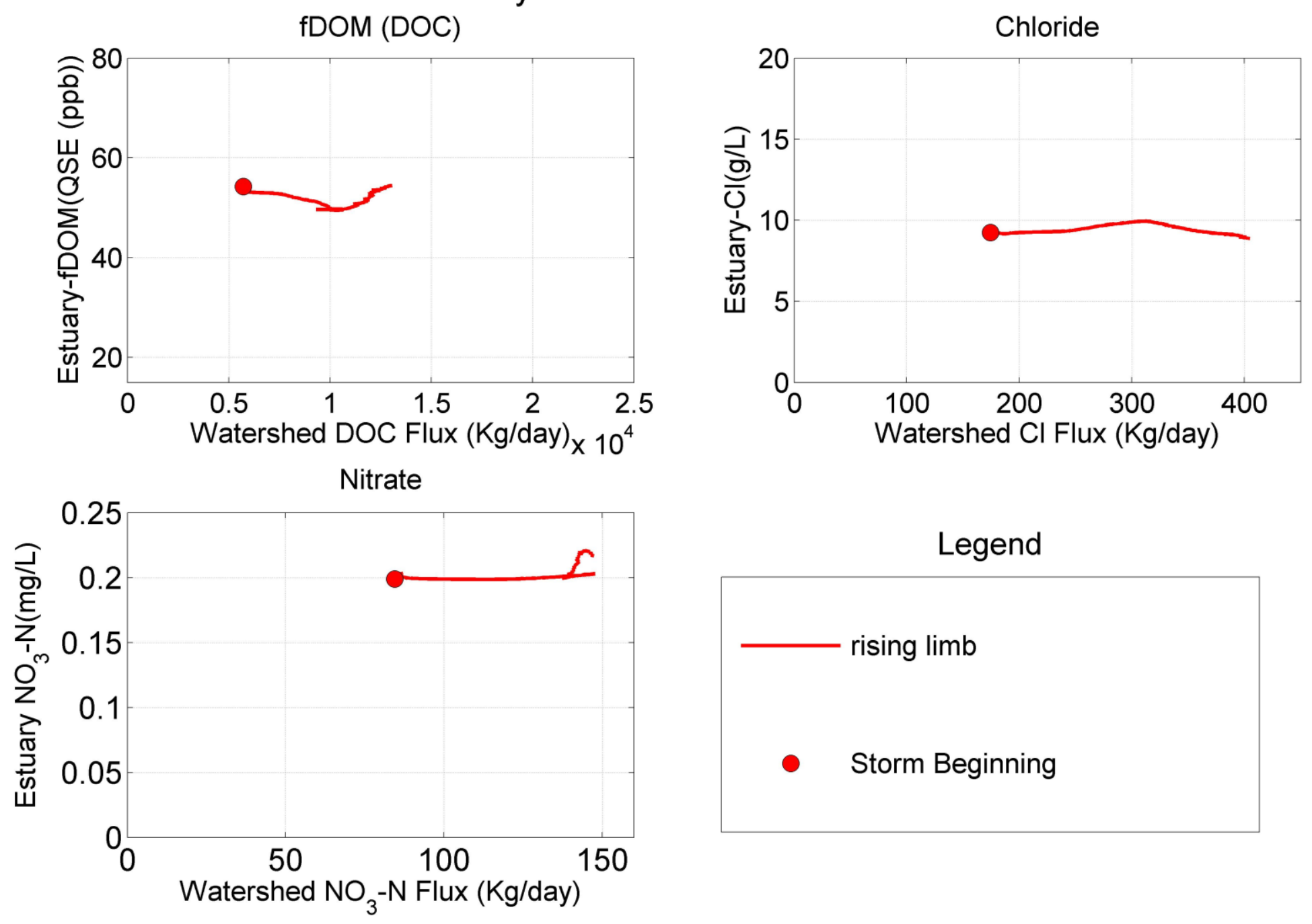

Figure S13 Hysteresis Pattern for one storm event, watershed variable ( fluxes of $\mathrm{DOC}, \mathrm{NO}_{3}$, and $\mathrm{Cl}$ ) Vs. Estuarine variable ( $\mathrm{fDOM}$, $\mathrm{NO}$, Cl). Only rising limb data is shown here. 
Aikman, F., \& Lanerolle, L. W. J. (2005). Report on the National Ocean Service Workshop on Residence / Flushing Times in Bays and Estuaries (No. September). NOAA. NOAA Technical Report NOS CS 20.

Bilgili, A., Proehl, J. A., Lynch, D. R., Smith, K. W., \& Swift, M. R. (2005). Estuary/ocean exchange and tidal mixing in a Gulf of Maine Estuary: A Lagrangian modeling study. Estuarine, Coastal and Shelf Science, 65(4), 607-624. https://doi.org/10.1016/j.ecss.2005.06.027

Menke, W., \& Menke, J. (2012). 9 - Detecting correlations among data. In W. Menke \& J. Menke (Eds.), Environmental Data Analysis with MatLab (pp. 167-201). Boston: Elsevier. http://dx.doi.org/10.1016/B978-0-12-391886-4.00009-X 